\title{
Carbon and Hydrogen Isotopic Reversals in Highly Mature Coal-Derived Gases: A Case Study of Paleozoic Gases in the Southern Ordos Basin, China
}

\author{
Dan Liu $\mathbb{D}^{1,2}$ \\ ${ }^{1}$ Institute of Geology and Geophysics, Chinese Academy of Sciences, Beijing 100029, China \\ ${ }^{2}$ Institute of Earth Science, Chinese Academy of Sciences, Beijing 100029, China \\ Correspondence should be addressed to Dan Liu; liudan@mail.iggcas.ac.cn
}

Received 12 February 2019; Revised 13 May 2019; Accepted 11 June 2019; Published 11 July 2019

Academic Editor: Francesco Italiano

Copyright (c) 2019 Dan Liu. This is an open access article distributed under the Creative Commons Attribution License, which permits unrestricted use, distribution, and reproduction in any medium, provided the original work is properly cited.

\begin{abstract}
The compositional carbon isotopic series $\delta^{13} \mathrm{C}-\mathrm{CH}_{4}<\delta^{13} \mathrm{C}-\mathrm{C}_{2} \mathrm{H}_{6}<\delta^{13} \mathrm{C}-\mathrm{C}_{3} \mathrm{H}_{8}<\delta^{13} \mathrm{C}-\mathrm{C}_{4} \mathrm{H}_{10}$ is common in thermogenic gases. With the exploration of deeper strata, however, isotopic reversals $\left(\delta^{13} \mathrm{C}-\mathrm{CH}_{4}>\delta^{13} \mathrm{C}-\mathrm{C}_{2} \mathrm{H}_{6}>\delta^{13} \mathrm{C}_{-} \mathrm{C}_{3} \mathrm{H}_{8}\right)$ in overmature unconventional shale gases and conventional (coal-derived) gases have been identified. Paleozoic gases in the southern Ordos Basin, China, with partial or complete isotopic reversals, were studied as examples of isotopic fractionation in overmature coal-derived gases. Isotopic compositions of gases of different maturities from the Ordos Basin and shale gases from around the world were compared. Results indicate that carbon isotopic series are related to maturity. Complete isotopic reversal occurs mostly in regions with vitrinite reflectance $\left(\mathrm{R}_{\mathrm{o}}\right)>2.4 \%$. Where $2.4 \%>\mathrm{R}_{\mathrm{o}}>2.0 \%$, almost all gases display partial isotopic reversal, with $\delta^{13} \mathrm{C}-\mathrm{CH}_{4}>\delta^{13} \mathrm{C}-\mathrm{C}_{2} \mathrm{H}_{6}$ or $\delta^{13} \mathrm{C}-\mathrm{C}_{2} \mathrm{H}_{6}>\delta^{13} \mathrm{C}-\mathrm{C}_{3} \mathrm{H}_{8}$. Carbon isotopic reversal in coal-derived gases is not caused by abiotic origin, the mixing of gases from different types of source rock, abiotic polymerization, wet gas cracking, and other mechanisms that contribute to reversal in shale gases. Based on the unique structure of coaly source rock and the geology of the Ordos Basin, closed-system aromatization-polycondensation reactions are considered the most likely cause of carbon isotopic reversal. During the reactions, isotopically light gases are generated by recombination of previously formed hydrocarbons and residual kerogencoal. Hydrogen isotopic reversal in the southern Ordos Basin might also be caused by aromatization-polycondensation reactions.
\end{abstract}

\section{Introduction}

The carbon isotopic composition of natural gas can be used to determine its origin, source, and maturity $[1,2]$. In thermogenic gas reactions, ${ }^{12} \mathrm{C}-{ }^{12} \mathrm{C}$ bonds usually break before ${ }^{12} \mathrm{C}-{ }^{13} \mathrm{C}$ bonds, resulting in kinetic isotopic fractionation [2] and causing natural gas to follow two evolutionary trends, with carbon isotopes becoming heavier as the component carbon number increases, forming a positive isotopic series with $\delta^{13} \mathrm{C}-\mathrm{CH}_{4}<\delta^{13} \mathrm{C}-\mathrm{C}_{2} \mathrm{H}_{6}<\delta^{13} \mathrm{C}-\mathrm{C}_{3} \mathrm{H}_{8}<\delta^{13} \mathrm{C}-\mathrm{C}_{4} \mathrm{H}_{10}$, and with each component $\mathrm{C}$ becoming enriched in ${ }^{13} \mathrm{C}$ as gas maturity increases [1].

As exploration of Paleozoic gas in the Ordos Basin has expanded into the southern part of the basin, more gases have been found to have carbon and hydrogen isotopic reversals. Most previous studies have attributed the partial carbon isotopic reversal $\left(\delta^{13} \mathrm{C}-\mathrm{CH}_{4}<\delta^{13} \mathrm{C}-\mathrm{C}_{2} \mathrm{H}_{6}>\delta^{13} \mathrm{C}\right.$ $\mathrm{C}_{3} \mathrm{H}_{8}$ ) of Ordos gases to the mixing of gases generated from different source rocks [3], (Yang et al., 2012), [4-7]. Recent studies have reported complete carbon isotopic reversals $\left(\delta^{13} \mathrm{C}-\mathrm{CH}_{4}>\delta^{13} \mathrm{C}-\mathrm{C}_{2} \mathrm{H}_{6}>\delta^{13} \mathrm{C}-\mathrm{C}_{3} \mathrm{H}_{8}\right)$ in Ordos gases [8-12], with all suggesting that such reversals are caused by high temperatures $\left(>200^{\circ} \mathrm{C}\right)$, with isotopic reversal in shale gas having the same mechanism. However, there are problems with this explanation as follows: (1) shale gas is an oil-type gas generated from type I and type II kerogen, whereas Ordos gas is mainly coal derived and generated from type III kerogen, with different gas-generation reactions occurring in these sources; (2) complete carbon isotopic reversal is universal in overmature shale gases [13-15], but not all overmature coal-derived gas has complete carbon isotopic reversals, as in gas from the southern Ordos Basin [16]; and 
(3) gases in the southern Ordos Basin display unique characteristics that differ from those of overmature shale gas, such as the evolutionary trend of hydrogen isotopes.

Here, the geochemical characteristics of southern Ordos gas and shale gas are compared, with isotopic fractionation of overmature coal-derived gas being considered separately from shale gas. Geochemical data for gases from other fields in the Ordos Basin with different maturities are considered to elucidate isotopic evolution in the Ordos Basin. The cause of hydrogen isotopic reversal in the southern Ordos Basin is also discussed.

\section{Geological Setting}

The Ordos Basin is the second largest sedimentary basin in China, with Paleozoic strata occurring over an area of $>250,000 \mathrm{~km}^{2}$ [16]. This basin is a petroliferous cratonic basin with stable subsidence, depression displacement, visible torsion, and multiple cycles of deposition [8]. Several giant gas fields, each containing $>100$ billion cubic metres (bcm) of proven gas reserves, have been discovered in the Paleozoic strata of the basin, with most gas being in the upper Paleozoic reservoirs such as the Sulige, Shenmu, Daniudi, and Yan'an gas fields. Upper Paleozoic and lower Paleozoic-Ordovician carbonate rocks provide the reservoir in the Jingbian field (Figure 1). Exploration of the Jingbian field has increased recently, with many wells being drilled in the overmature southern Jingbian area, targeting both lower and upper Paleozoic gas systems [16] and providing an unprecedented opportunity to improve our understanding of the geochemistry of overmature gas systems.

2.1. Source Rocks. The predominant source rock of Paleozoic gases is Carboniferous-Permian (C-P) coal and mudstone. Ordovician marine carbonates contribute only minor amounts of gas owing to their low organic content. Previous studies indicate that gases of the Sulige, Daniudi, Shenmu, Wushenqi, Yulin, Zizhou, and Mizhi fields were all produced from upper Paleozoic coaly source rocks [4, 17-20]. The origin of Jingbian gas, from the lower Paleozoic-Ordovician Majiagou formation, is still unresolved, although the prevailing view is that it was produced mainly from upper Paleozoic coal measures, migrated downward, and mixed with oil-type gas from lower Paleozoic-Ordovician source rocks [11, 21].

2.2. Reservoirs. The two main reservoirs in the Paleozoic strata of the Ordos Basin are the upper C-P paralic and continental clastic reservoir and lower Paleozoic (Ordovician) marine carbonate reservoir. Most natural gas from the Sulige, Daniudi, Shenmu, Wushenqi, Yulin, Zizhou, and Mizhi fields is produced from the upper Paleozoic reservoirs, with tight sandstones of the Permian Shanxi and Xiashihezi formations being the major reservoirs. Gas of the Jingbian field is produced from both the upper and lower Paleozoic reservoirs, with the major lower Paleozoic reservoir being the fifth member $\left(\mathrm{O}_{1} \mathrm{~m}_{5}\right)$ of the Majiagou formation.

2.3. Caprocks. Caprocks of the lower Paleozoic reservoirs are Carboniferous bauxitic mudstones that are $<10 \mathrm{~m}$ thick, coal measures that are $15-40 \mathrm{~m}$ thick, and argillaceous dolomite and marlstone [21]. The regional seal of the upper Paleozoic reservoirs consists of stable, laterally distributed, Shangshihezi and Shiqianfeng formation lacustrine mudstones [16].

2.4. Thermal History and Gas Charge Model. During the Late Triassic-Early Jurassic $\left(\mathrm{T}_{3}-\mathrm{J}_{1}\right)$, at the threshold of hydrocarbon generation, the gas first accumulated within C-P source rocks. During the Late Jurassic-Early Cretaceous $\left(\mathrm{J}-\mathrm{K}_{1}\right)$, $>1000 \mathrm{~m}$ of $\mathrm{J}-\mathrm{K}_{1}$ sediment was deposited, with a maximum depth of $>4000 \mathrm{~m}$ and a maximum palaeogeothermal temperature of $160-200^{\circ} \mathrm{C}$. Most C-P gases were generated during this period and migrated to nearby upper Paleozoic $\mathrm{C}-\mathrm{P}$ reservoirs between source rocks. Driven by buoyancy and abnormal pressure, the gases also migrated directly upward or downward into the lower Paleozoic reservoirs over distances of $<200 \mathrm{~m}[16,21,22]$. From the end of the Early Cretaceous, thick strata were eroded and gas generation terminated, with the temperature reducing to the current $99.6-113.5^{\circ} \mathrm{C}[23]$

\section{Sampling and Analysis}

3.1. Data Analyses. Geochemical characteristics of 199 gas samples from Paleozoic reservoirs in the Ordos Basin gas fields, including the Jingbian, Yan'an, Sulige, Shenmu, and Daniudi fields (Figure 1), are presented in Table 1. The data pertain to 94 samples from previous studies [9, 16], 41 from newly collected samples in this study, and 64 recorded in the geochemical database of the Exploration and Development Research Institute, Changqing Oil Company (EDRICOC), Xi'an, China. Eight of the 27 samples of Feng et al. [9] were analysed for rare-gas isotopes (Table 1). Data for the gas samples were obtained using similar techniques $[11,16]$ to ensure consistency. The maturity of the upper Paleozoic source rocks in the Ordos Basin increases from north to south, and the gases come from similar source rocks, so a comparison of isotopic compositions of gases in these fields may provide information on the evolution of coalderived gases based on geological setting. Lower Paleozoic South Jingbian gases are included in the discussion of the origin of isotopic reversal. Shale gas from the Sichuan Basin and other basins with different maturities is included to provide information on differences between coal-derived and oil-type gases (data for shale gas were obtained from [13-16, 24-31]). Shale gases also display isotopic reversal in high maturity conditions, providing insight into the origin of unusual geochemical characteristics of overmature coal-derived gases.

3.2. Geochemical and C-H Isotopic Analyses. Analyses of gas composition and $\mathrm{C}$ and $\mathrm{H}$ isotopic ratios were conducted at the Institute of Petroleum Exploration and Development (RIPED), Langfang, China. A Hewlett Packard HP7890A capillary gas chromatograph was used to determine hydrocarbon compositions with a PLOT $\mathrm{Al}_{2} \mathrm{O}_{3}$ column $(50 \mathrm{~m} \times 0.53 \mathrm{~mm})$.

Carbon isotopic compositions were determined by gas chromatography-combustion-isotope ratio mass spectrometry 


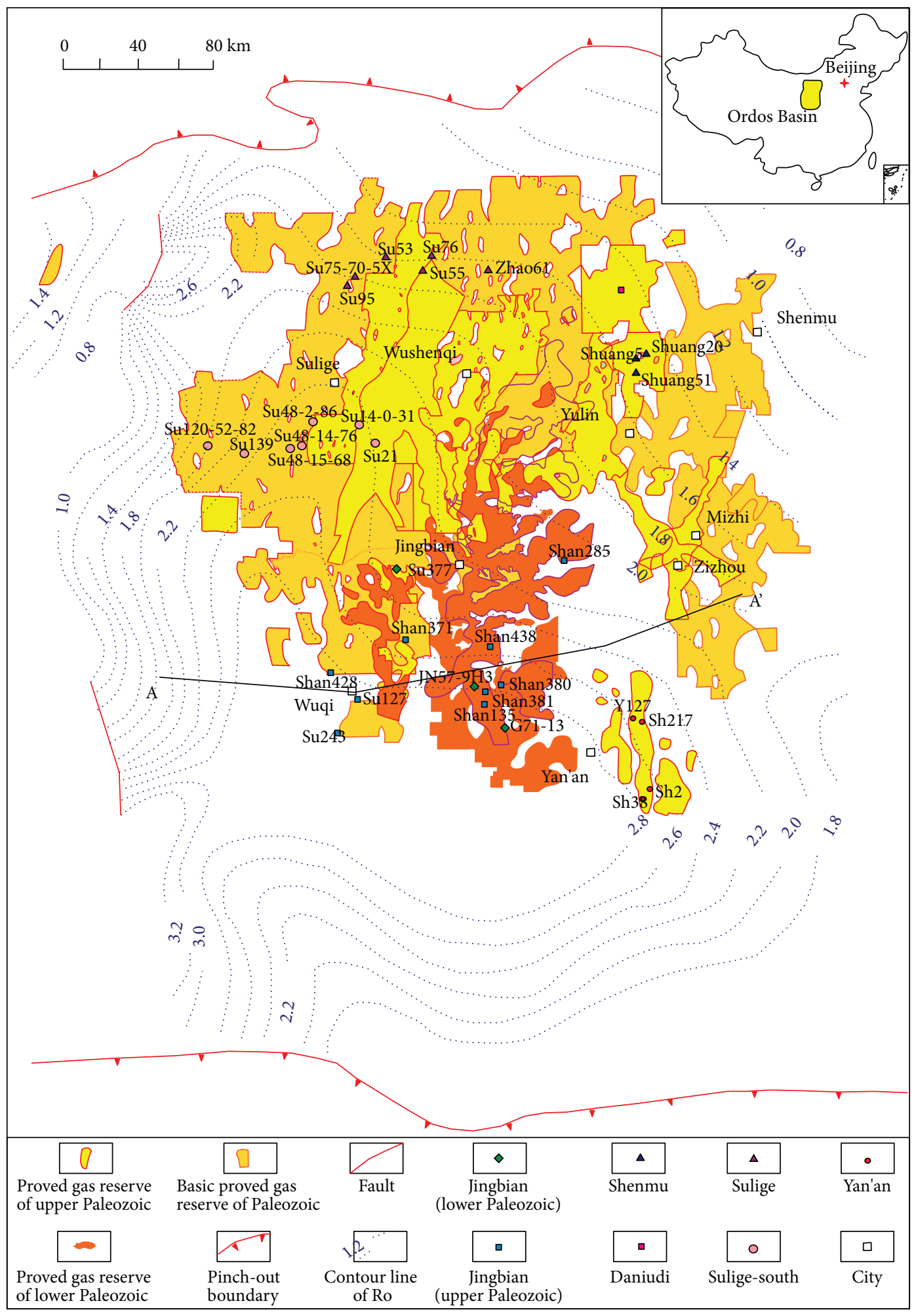

(a)

FIGURe 1: Continued. 


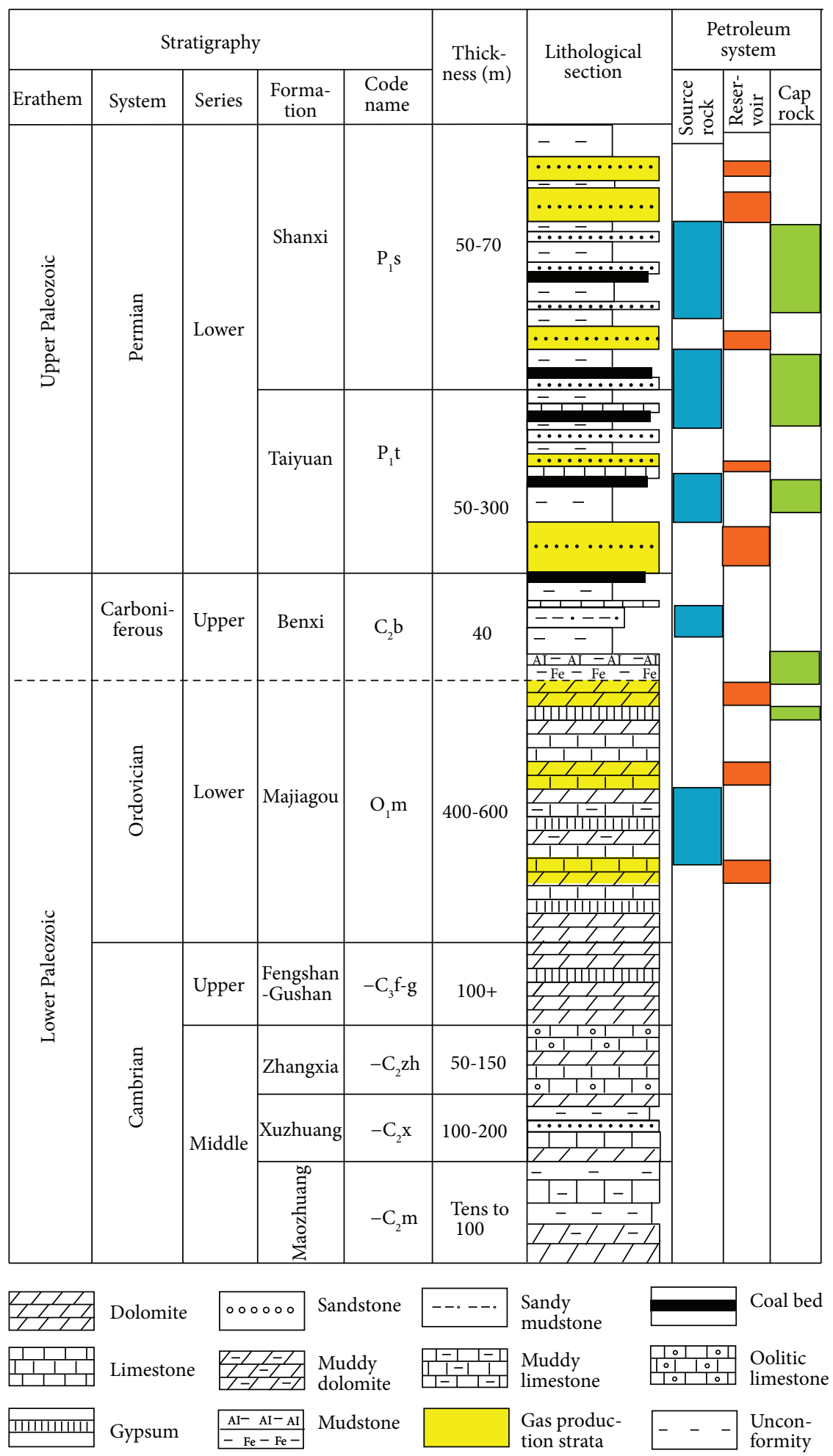

(b)

FIgure 1: Continued. 


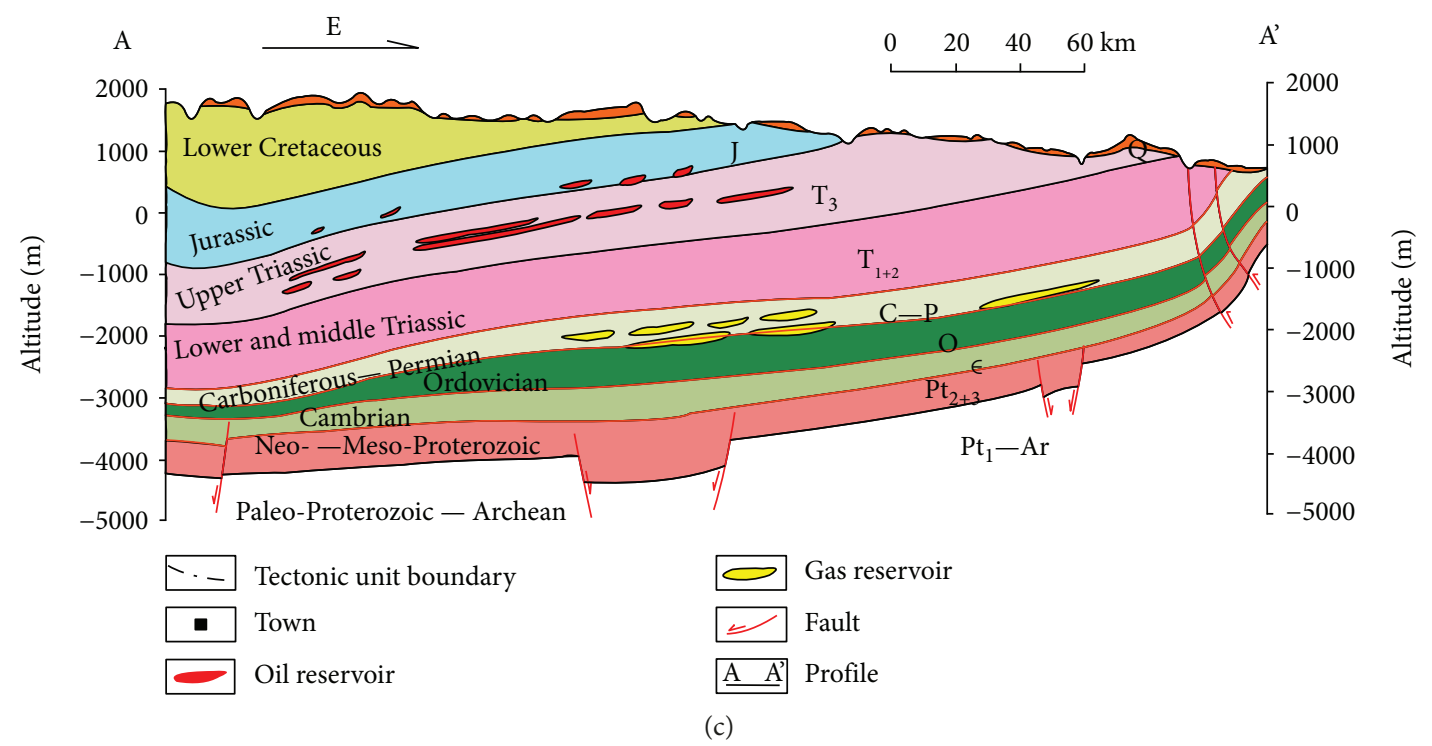

Figure 1: (a) Maturity map of the upper Paleozoic strata of the Ordos Basin, with sample locations labelled by well name (after [16]); (b) stratigraphic column of the Paleozoic strata of the Ordos Basin (after [16]); (c) cross section for Ordos Basin (after [16]).

(GC-C-IRMS; Thermo Delta V Advantage). Each sample was analysed three times, yielding an analytical precision of $\pm 0.3 \%$. Results are reported relative to Vienna Pee Dee Belemnite (VPDB). Hydrogen isotopes were analysed by GC-thermal conversion-IRMS (GC-TC-IRMS; Finnigan MAT 253), using a HP-PLOTQ GC column $(30 \mathrm{~m} \times 0.32 \mathrm{~mm})$. Analytical precision was $\pm 3 \%$. Hydrogen isotopic compositions are reported relative to Vienna Standard Mean Ocean Water (VSMOW). The detailed analytical procedure is described in Feng et al. [9].

3.3. He Isotopic Composition. Seventeen gas samples were analysed at RIPED for $\mathrm{He}$ content and ${ }^{3} \mathrm{He} /{ }^{4} \mathrm{He}$ ratios using a sampling system attached to an IRMS. The natural gas cylinder was connected to the injection port of the instrument through a pressure relief valve, with the pipeline evacuated to ultrahigh vacuum. Sampling was controlled by an injection valve, and the gas was purified of hydrocarbons, $\mathrm{N}_{2}$, $\mathrm{O}_{2}, \mathrm{CO}_{2}, \mathrm{H}_{2} \mathrm{~S}$, and $\mathrm{H}_{2}$, by a zirconium base furnace. $\mathrm{He}$, $\mathrm{Ne}, \mathrm{Ar}, \mathrm{Kr}$, and Xe were separated cryogenically and analysed by MS. Based on internationally recognized contents of inert gases in air, the relative standard deviations of He content and ${ }^{3} \mathrm{He} /{ }^{4} \mathrm{He}$ ratio were $\pm 3.4 \%$ and $\pm 4.5 \%$, respectively.

\section{Results}

4.1. Natural Gas Composition. Southern Ordos Basin gases from the Yan'an and South Jingbian gas fields are of high dryness, with dryness coefficients $\left(\mathrm{C}_{1} / \mathrm{C}_{1-5}\right)>0.962$ (Table 1), and their cumulative contents of heavier hydrocarbon components $\left(\mathrm{C}_{2-5}\right)$ are low (Figure 2). Ethane content is $0.05 \%-2.68 \%$ (mean $0.51 \%$ ), and propane content is $<0.60 \%$ for Paleozoic gases from both fields. Concentrations of nonhydrocarbon gases, including $\mathrm{CO}_{2}$ and $\mathrm{N}_{2}$, vary widely. $\mathrm{CO}_{2}$ and $\mathrm{N}_{2}$ concentrations in the Yan'an gas field are relatively low at $0.56 \%-31.54 \%$ (mean $4.38 \%$ ) and $0.00 \%-32.68 \%$ (mean 5.23\%), respectively, whereas the nonhydrocarbon content of South Jingbian gas is high, with its methane content being relatively low. The $\mathrm{CO}_{2}$ content of lower Paleozoic gas from the Jingbian gas field is $0.44 \%-31.54 \%$ (mean 6.61\%), whereas the $\mathrm{N}_{2}$ content of upper Paleozoic gas is $0.26 \%-33.7 \%$ (mean $7.07 \%$ ). The high $\mathrm{CO}_{2}$ content of lower Paleozoic South Jingbian gas is probably due to its carbonate reservoir. Upper Paleozoic gases are contained in Carboniferous-Permian reservoirs, whereas lower Paleozoic gases are from Ordovician carbonate reservoirs, and it is likely that the high $\mathrm{CO}_{2}$ content of the latter arose from the cracking of Ordovician carbonates. High temperatures are necessary for the thermal cracking of carbonate, whereas the existence of acidic water in the Ordovician reservoir [16] makes the generation of $\mathrm{CO}_{2}$ possible at any temperature.

Gases from the central and northern Ordos Basin (Sulige, Shenmu, and Daniudi fields) have compositions different to those of gases from the southern basin (South Jingbian and Yan'an fields; Figure 2). Gases from the central and northern fields are relatively wet, with dryness coefficients $<0.983$ (mean 0.941); their heavy hydrocarbon contents are higher (ethane mean 3.04\%); and nonhydrocarbon contents lower $\left(\mathrm{N}_{2}\right.$ and $\mathrm{CO}_{2}$ means $1.86 \%$ and $3.07 \%$, respectively). These characteristics are consistent with the $\mathrm{R}_{\mathrm{o}}$ distribution of source rocks in the Ordos Basin (Figure 1). Differences in hydrocarbon content indicate that gases from the southern Ordos Basin have been exposed to higher palaeogeothermal stress and were generated in a later evolutionary stage, whereas their nonhydrocarbon content could be explained by some secondary mechanism occurring in a late maturity stage.

4.2. Carbon Isotopic Compositions of Alkanes and $\mathrm{CO}_{2}$. Gas $\delta^{13} \mathrm{C}_{-} \mathrm{CH}_{4}$ values in the upper Paleozoic reservoir of the South Jingbian and Yan'an gas fields range from $-21.02 \%$ 


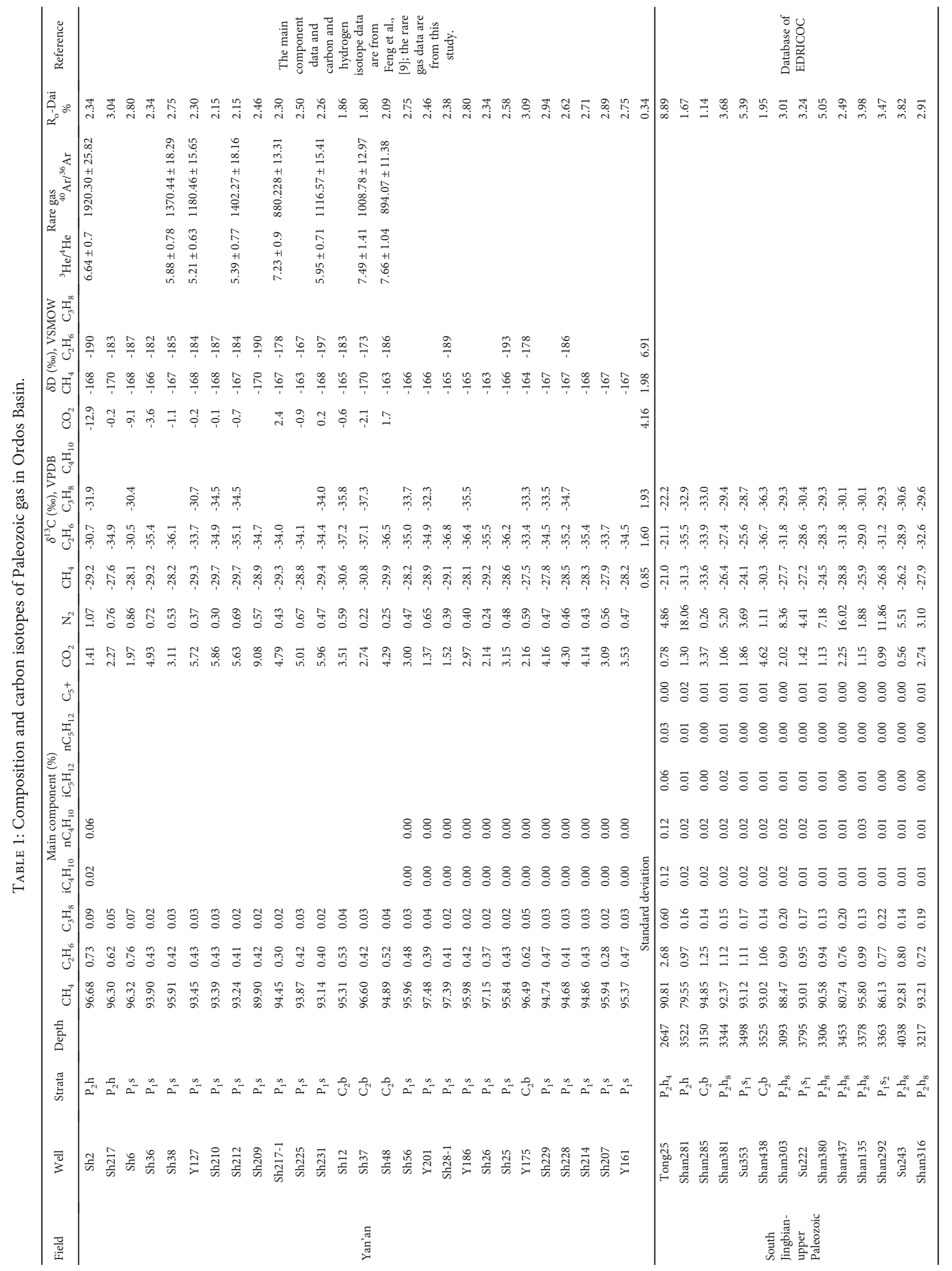




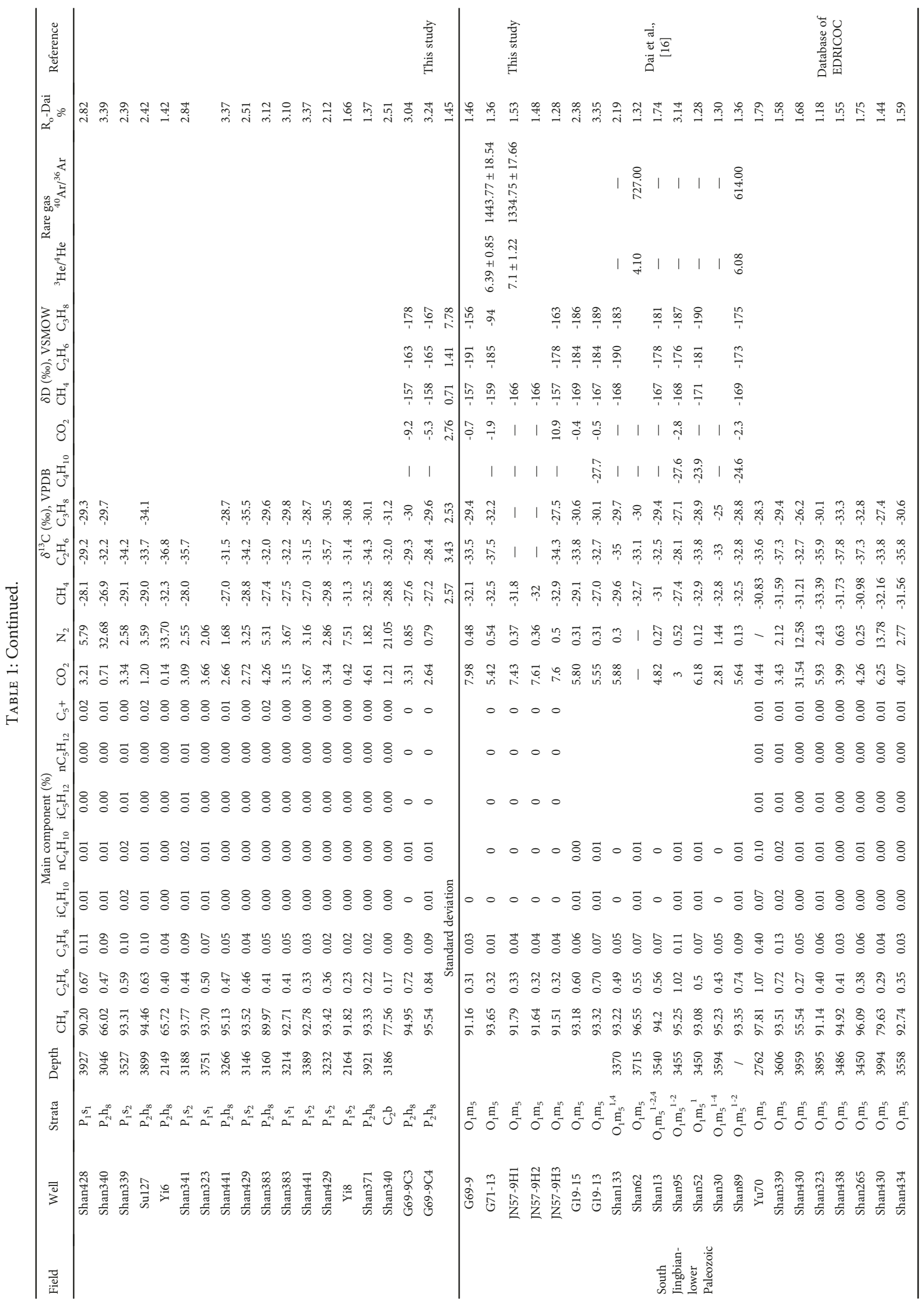




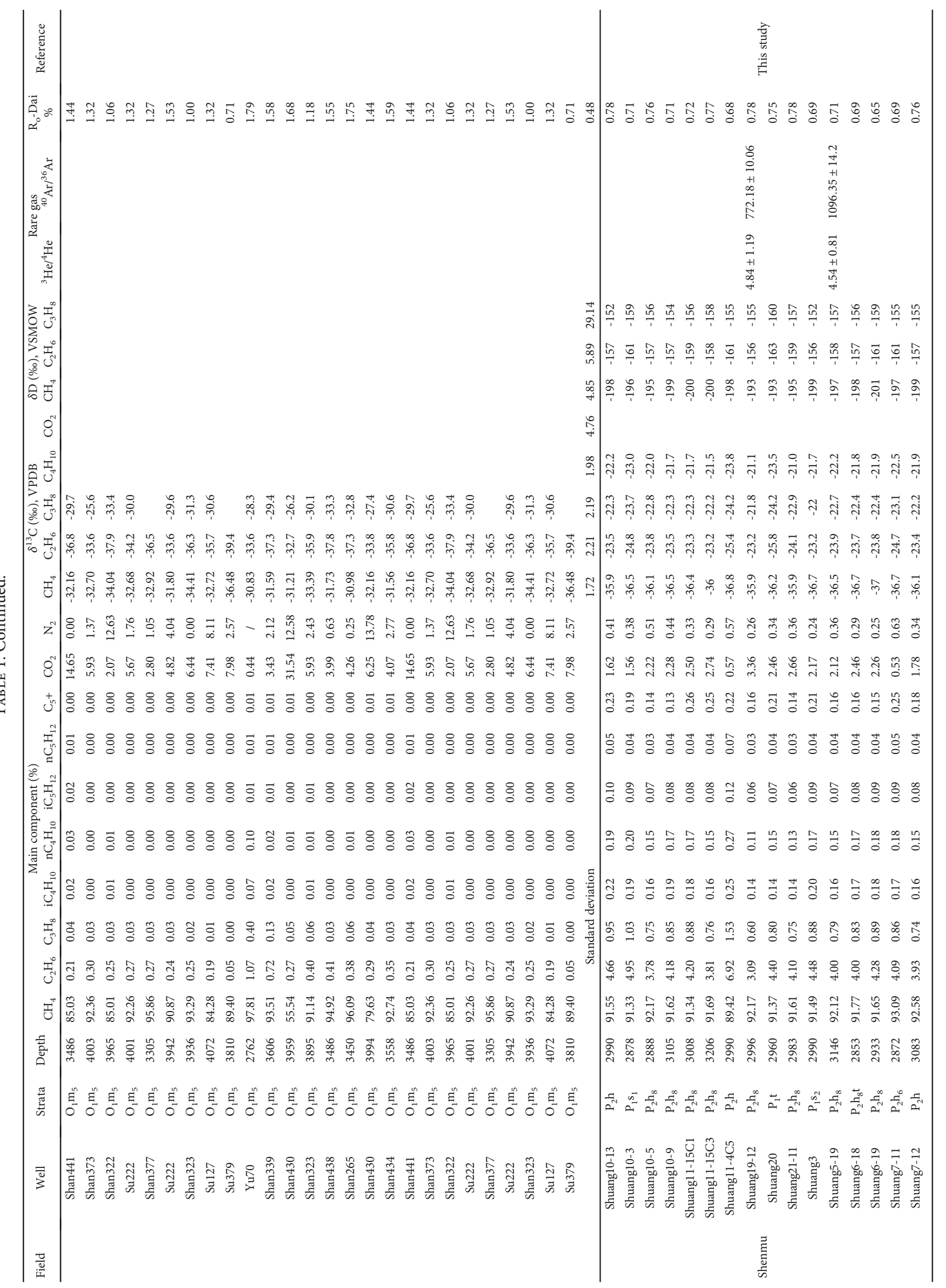




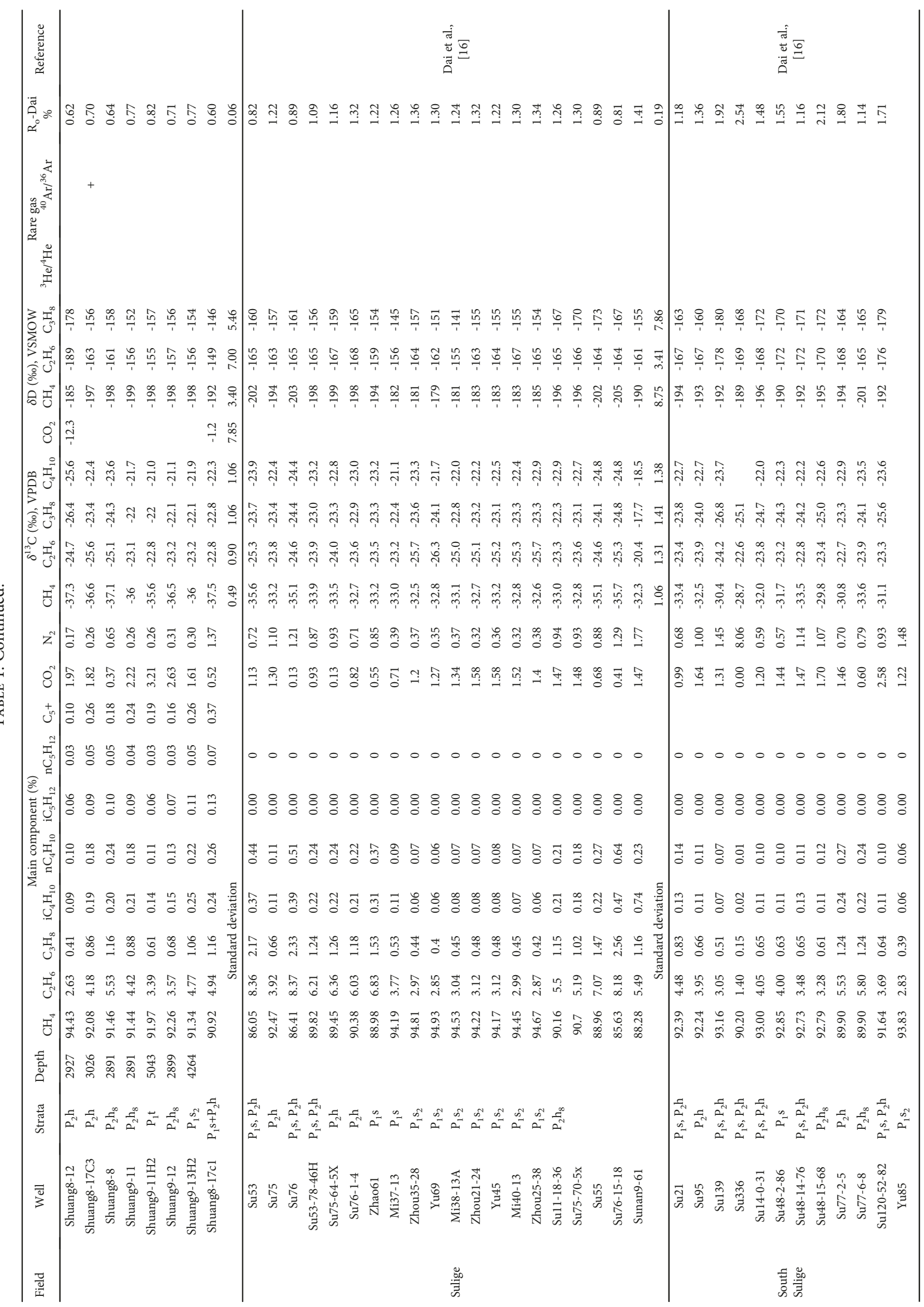




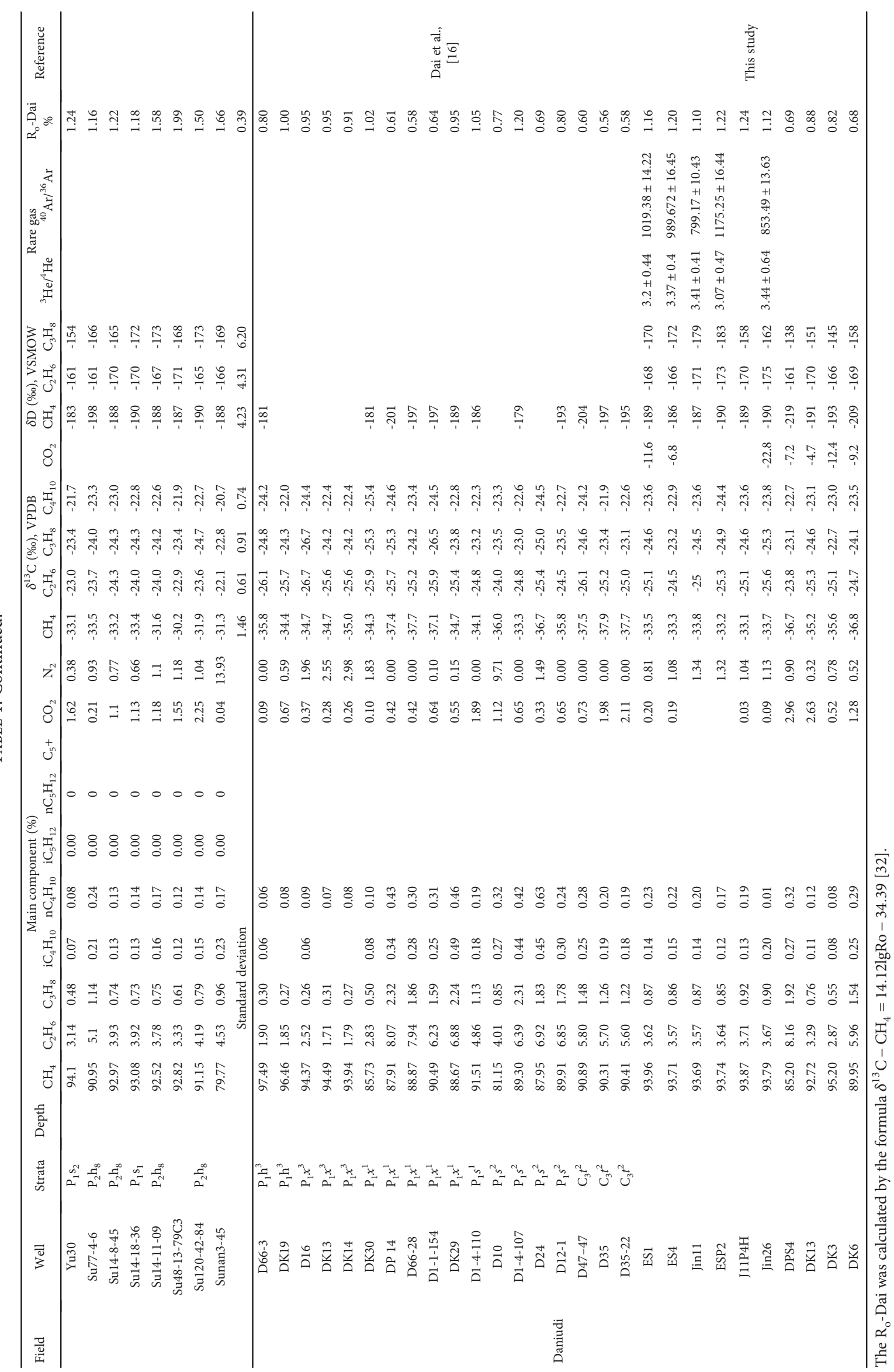




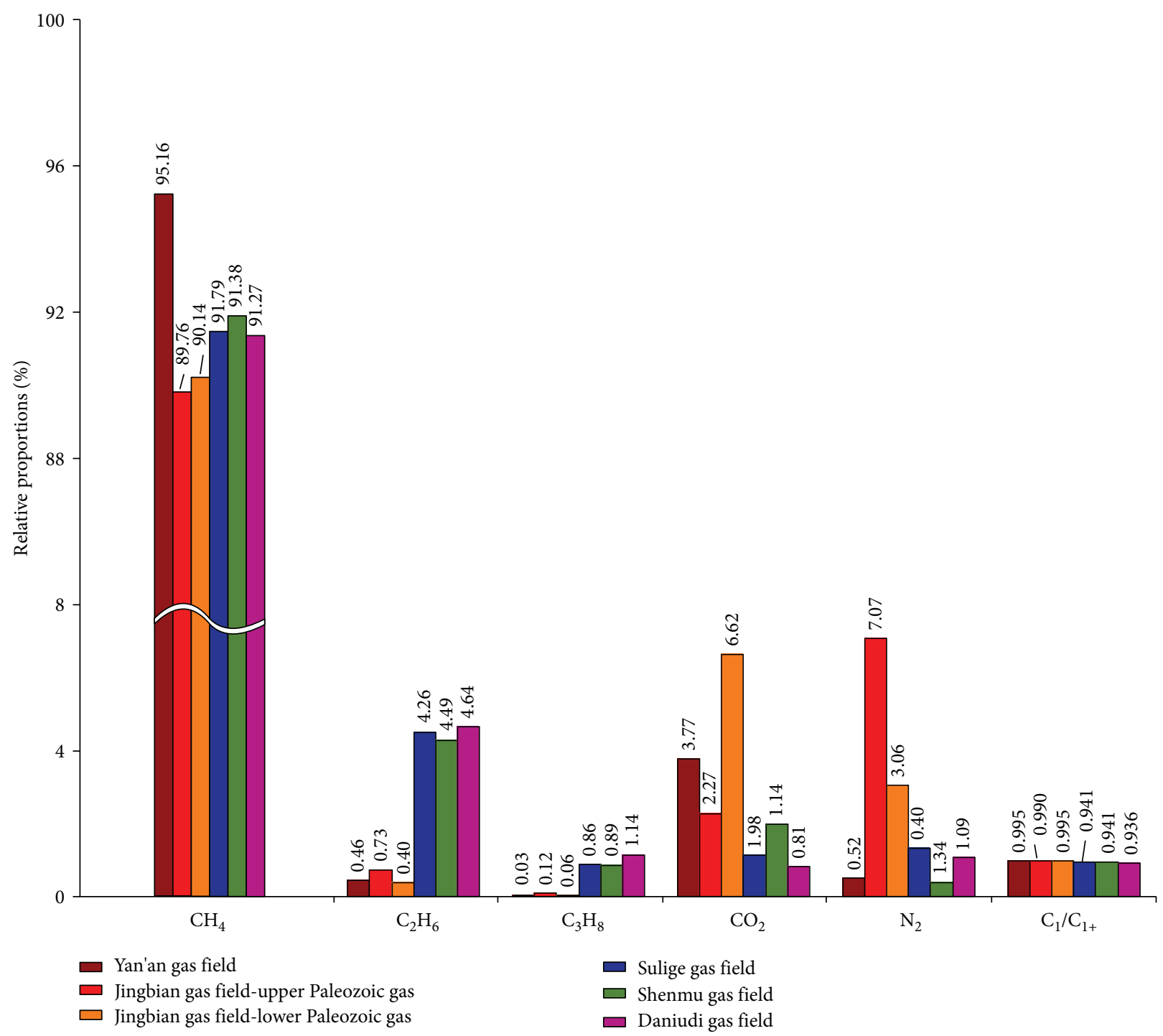

FIGURE 2: Relative proportions and dryness coefficients of gas components of natural gas in gas fields of the Ordos Basin.

to $-33.62 \%$ (SD $2.57 \%$ ) and $-27.5 \%$ to $-30.8 \%$ (SD $0.85 \%$ ), respectively, with heavier isotopic compositions than those of upper Paleozoic coal-derived gases from other Ordos Basin gas fields such as the Sulige, Shenmu, and Daniudi fields (Table 1; Figure 3). In contrast, most upper Paleozoic gases from the southern Ordos Basin have unusually light $\delta^{13} \mathrm{C}-\mathrm{C}_{2} \mathrm{H}_{6}$ values, with those of South Jingbian gas averaging $-31.5 \%$ and Yan'an gas averaging $-34.8 \%$, which are lighter than typical coal-derived gases $(\geq 29 \%$ ). Equivalent vitrinite reflectance values of the sources of gases of the upper Paleozoic South Jingbian and Yan'an are in the range $1.14-5.39 \% \mathrm{R}_{\mathrm{o}}\left(\mathrm{SD} 1.45 \% \mathrm{R}_{\mathrm{o}}\right)$ and $1.80-3.09 \% \mathrm{R}_{\mathrm{o}}(\mathrm{SD}$ $0.34 \% \mathrm{R}_{\mathrm{o}}$ ), respectively, with the reflectance values of most of these gases being in the range $2.0-3.5 \% \mathrm{R}_{\mathrm{o}}$, based on the relationship proposed by Dai et al. [32] for gases generated from type III kerogen-coal $\left(\delta^{13} \mathrm{C}-\mathrm{CH}_{4}=14.12 ; 34.39 \% \mathrm{R}_{\mathrm{o}}\right)$, consistent with measured vitrinite reflectance of coal source rocks in the upper Paleozoic strata (Figure 1).
Compared with upper Paleozoic South Jingbian gases, lower Paleozoic gases contain alkanes more depleted in ${ }^{13} \mathrm{C}$, with $\delta^{13} \mathrm{C}_{-} \mathrm{CH}_{4}$ values of $-27.00 \%$ to $-36.48 \%$ (mean $-32.05 \%$, SD $1.72 \%$ o) and $\delta^{13} \mathrm{C}-\mathrm{C}_{2} \mathrm{H}_{6}$ values of $-28.10 \%$ to $-39.42 \%$ o (mean $-35.06 \%$, SD $2.21 \%$ ). The equivalent vitrinite reflectance of lower Paleozoic gas sources, calculated as proposed by Dai et al. [32] for coal-derived gas, is in the range $0.71-3.35 \% \mathrm{R}_{\mathrm{o}}$ (mean $1.50 \% \mathrm{R}_{\mathrm{o}}$, $\mathrm{SD} 0.48 \% \mathrm{R}_{\mathrm{o}}$ ). Calculated $\mathrm{R}_{\mathrm{o}}$ values for lower Paleozoic source rocks of South Jingbian gas are lower than those of upper Paleozoic source rocks in the same region (Figure 1), indicating two possibilities: that the gas is not coal-derived and the calculation method is therefore inapplicable or that the gases were generated from other coal source rocks of lower maturity than the upper Paleozoic source rocks. Jurassic coaly source rock has lower maturity than C-P coaly source rock, although it produces mainly oil and there is no pathway for any gas generated to migrate to the lower Paleozoic reservoir, 


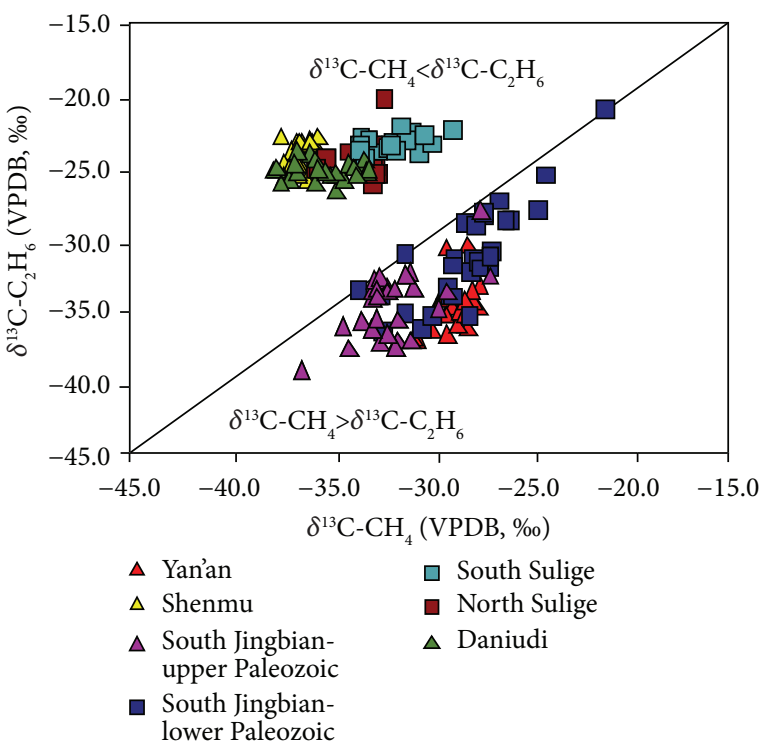

(a)

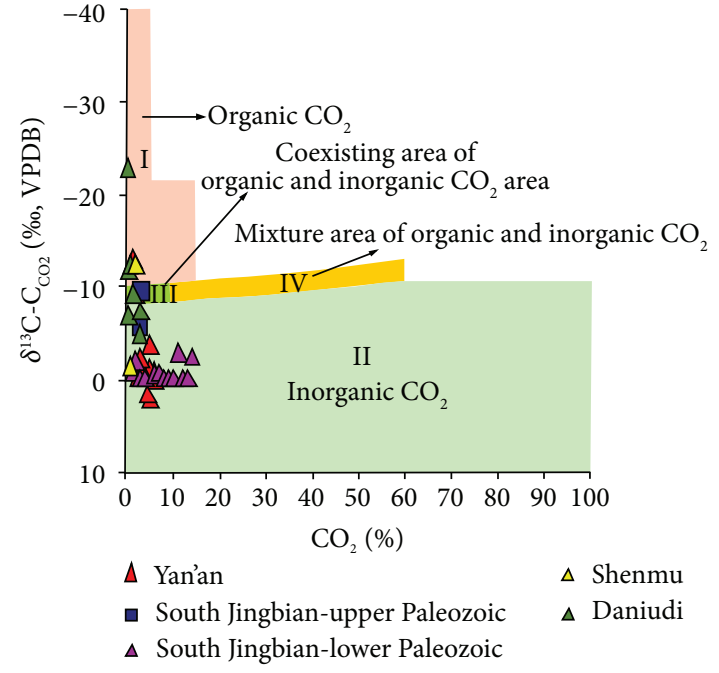

(b)

Figure 3: (a) Plot of $\delta^{13} \mathrm{C}-\mathrm{C}_{2} \mathrm{H}_{6}$ versus $\delta^{13} \mathrm{C}-\mathrm{CH}_{4}$; (b) relationship between $\delta^{13} \mathrm{C}-\mathrm{CO}_{2}$ and $\mathrm{CO}_{2}$ content of gases in different gas fields of the Ordos Basin (modified from [33]). Note: symbols for samples from different areas of the Ordos Basin are used in all subsequent figures.

precluding the second possibility. Type I and type II kerogen occur in lower Paleozoic Ordovician source rocks [11, 34], so oil-type gases generated there could be mixed with lower Paleozoic gases, and the $\mathrm{R}_{\mathrm{o}}-\delta^{13} \mathrm{C}-\mathrm{CH}_{4}$ relationship is not applicable to mixed gases. It appears, therefore, that geochemical differences between lower and upper Paleozoic South Jingbian gases indicate that they are produced from different sources.

Thrasher and Fleet [35] reported that the $\delta^{13} \mathrm{C}$ values for large gas accumulations (over 15 vol.\% of $\mathrm{CO}_{2}$ ) are in the range $-10 \%$ to $0 \%$, suggesting an inorganic origin. In contrast, gas accumulations that have less than 15 vol.\% of $\mathrm{CO}_{2}$ and low $\delta^{13} \mathrm{C}-\mathrm{CO}_{2}$ values $(<10 \%)$ are of organic origin. Dai et al. [33] reviewed the distribution of $\delta^{13} \mathrm{C}-\mathrm{CO}_{2}$ values in Chinese basins and proposed a model of $\mathrm{CO}_{2}$ production in which gases of organic origin contain $<15 \% \mathrm{CO}_{2}$ with $\delta^{13} \mathrm{C}-\mathrm{CO}_{2}$ values below $-10 \%$, whereas gases of inorganic origin contain $>60 \% \mathrm{CO}_{2}$ with $\delta^{13} \mathrm{C}-\mathrm{CO}_{2}$ values of $-8 \%$ o to $-3 \%$. The $\delta^{13} \mathrm{C}-\mathrm{CO}_{2}$ values of 23 Ordos Basin gas samples range from $-12.9 \%$ o to $10.9 \%$, with 20 having values above $-8 \%$ (Figure 3(b), Table 1), indicating an inorganic origin. Considering that a unit of thick limestone occurs in the Benxi $\left(\mathrm{C}_{2} \mathrm{~b}\right)$ and Taiyuan $\left(\mathrm{P}_{1} \mathrm{t}\right)$ formations in the Ordos Basin, it is likely that $\mathrm{CO}_{2}$ was produced by the cracking of inorganic carbonates. The C-P coaly source rock generated organic acid while approaching and reaching maturation [16], with the palaeotemperature reaching $160-200^{\circ} \mathrm{C}$. These factors created a favourable environment for the generation of $\mathrm{CO}_{2}$.

4.3. Hydrogen Isotopic Composition. The hydrogen isotopic composition of methane $\left(\delta \mathrm{D}-\mathrm{CH}_{4}\right)$ of natural gas in the southern Ordos Basin is heavy compared with that of the other gas fields (Figure 4(a)). Yan'an gas $\delta \mathrm{D}-\mathrm{CH}_{4}$ values range from $-163.0 \%$ to $-170.0 \%$ o (mean $-166.6 \%$, SD $1.98 \%$ ). Lower Paleozoic South Jingbian gases have similar hydrogen isotopic compositions, with $\delta \mathrm{D}-\mathrm{CH}_{4}$ values of $-157 \%$ o to $-171 \%$ o (mean $-165.33 \%$, SD $4.85 \%$ ). The heavy $\delta \mathrm{D}-\mathrm{CH}_{4}$ values of Yan'an and South Jingbian gases are consistent with their high maturities. The hydrogen isotopic compositions of ethane $\left(\delta \mathrm{D}-\mathrm{C}_{2} \mathrm{H}_{6}\right)$ of southern Ordos Basin gases are light compared with those of gases from all other Ordos Basin fields (Table 1). The $\delta \mathrm{D}-\mathrm{C}_{2} \mathrm{H}_{6}$ values of Yan'an gases range from $-167.0 \%$ to $-197.0 \%$ (mean $-184.3 \%$, SD $6.91 \%$ ), whereas those of South Jingbian gases range from $-173.0 \%$ o to $-191.0 \%$ o (mean $-182.0 \%$, SD $5.89 \%$ ). Gases of the southern Ordos Basin thus display hydrogen isotopic reversal $\left(\delta \mathrm{D}-\mathrm{CH}_{4}>\delta \mathrm{D}-\mathrm{C}_{2} \mathrm{H}_{6}\right)$ (Figure $\left.4(\mathrm{~b})\right)$.

4.4. Carbon Isotopic Reversal in Gases from the Southern Ordos Basin. Carbon isotopic reversal is a distinctive feature of Paleozoic natural gas of the southern Ordos Basin (Figure 5). The lower Paleozoic South Jingbian gases all display partial reversal $\left(\delta^{13} \mathrm{C}-\mathrm{CH}_{4}>\delta^{13} \mathrm{C}-\mathrm{C}_{2} \mathrm{H}_{6}<\delta^{13} \mathrm{C}-\mathrm{C}_{3} \mathrm{H}_{8}\right)$, whereas upper Paleozoic gases display partial $\left(\delta^{13} \mathrm{C}-\mathrm{CH}_{4}>\right.$ $\left.\delta^{13} \mathrm{C}-\mathrm{C}_{2} \mathrm{H}_{6}<\delta^{13} \mathrm{C}-\mathrm{C}_{3} \mathrm{H}_{8}\right)$ or complete $\left(\delta^{13} \mathrm{C}-\mathrm{CH}_{4}>\delta^{13} \mathrm{C}\right.$ $\left.\mathrm{C}_{2} \mathrm{H}_{6}>\delta^{13} \mathrm{C}-\mathrm{C}_{3} \mathrm{H}_{8}\right)$ reversals, and Yan'an gases display complete reversals. For all Ordos Basin upper Paleozoic gas fields, there is a strong relationship between maturity (indicated by $\mathrm{R}_{\mathrm{o}}$ values) and carbon isotopic series (Figures 1(a) and 5; Table 2).

On the basis of the new data and the results of previous studies, some preliminary conclusions can be drawn as follows. A large portion of the gases with complete carbon isotopic reversal appears in regions with $R_{o}>2.4 \%$, but not all gases from such regions display complete reversal (some 


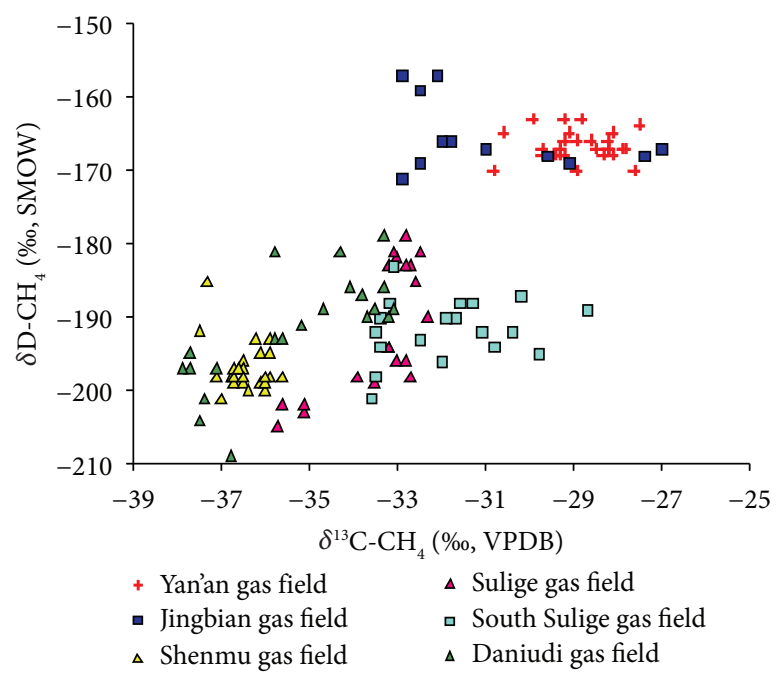

(a)

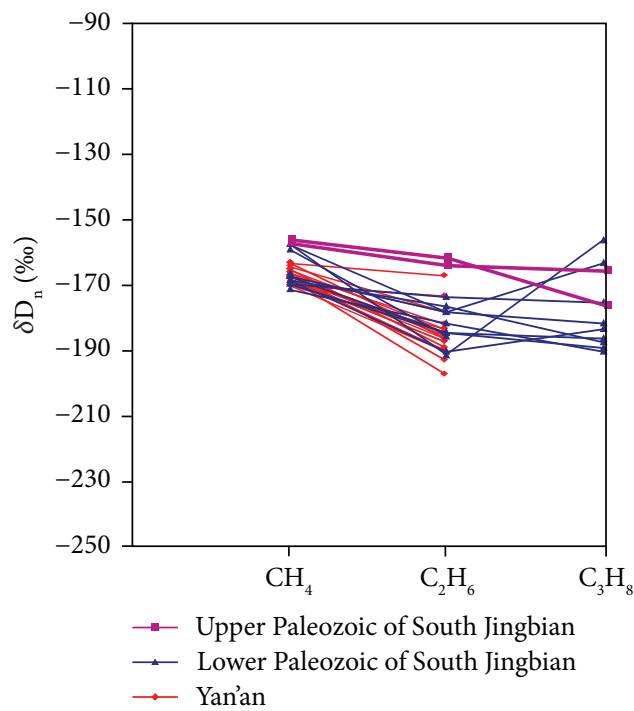

(b)

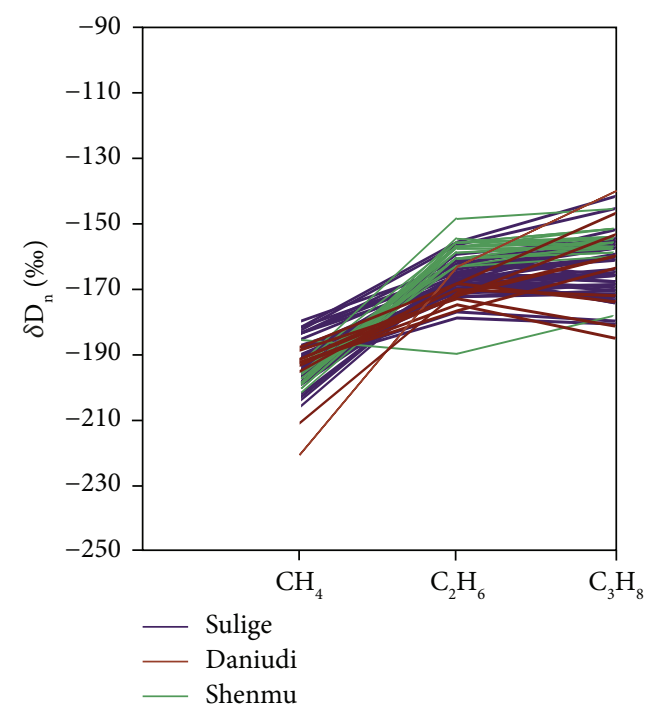

(c)

Figure 4: (a) Plot of $\delta \mathrm{D}-\mathrm{CH}_{4}$ versus $\delta^{13} \mathrm{C}-\mathrm{CH}_{4}$; (b) hydrogen isotopic series of alkanes in lower and upper Paleozoic gases of South Jingbian and Yan'an gas fields (all gases show hydrogen isotopic reversal with $\delta \mathrm{D}-\mathrm{CH}_{4}>\delta \mathrm{D}-\mathrm{C}_{2} \mathrm{H}_{6}$ ); (c) hydrogen isotopic series of alkane gases in Sulige, Daniudi, and Shenmu gas fields (with positive hydrogen isotopic series).

have partial reversals); in regions with $2.4 \%>\mathrm{R}_{\mathrm{o}}>2.0 \%$, almost all gases display partial reversals, some with $\delta^{13} \mathrm{C}$ $\mathrm{CH}_{4}>\delta^{13} \mathrm{C}-\mathrm{C}_{2} \mathrm{H}_{6}$ and others with $\delta^{13} \mathrm{C}-\mathrm{C}_{2} \mathrm{H}_{6}>\delta{ }^{13} \mathrm{C}-\mathrm{C}_{3} \mathrm{H}_{8}$; and most gases from regions with $\mathrm{R}_{\mathrm{o}}<2.0 \%$ display positive carbon isotopic series. The correlation between carbon isotopic series in Paleozoic Ordos Basin gases and gas maturity indicates that isotopic reversal may be caused by elevated temperatures.

4.5. Carbon Isotopic Evolution in Gases of Different Maturity. As observed for shale gases of varying maturity, carbon isotopic compositions of methane and ethane indicate different evolutionary trends, with $\delta^{13} \mathrm{C}-\mathrm{CH}_{4}$ values increasing with decreasing wetness and $\delta^{13} \mathrm{C}-\mathrm{C}_{2} \mathrm{H}_{6}$ values first increasing and then decreasing with decreasing wetness (Figure 6). The evolution of mainly coal-derived natural gases in the
Paleozoic strata of the Ordos Basin can be divided into two zones in terms of $\delta^{13} \mathrm{C}-\mathrm{C}_{2} \mathrm{H}_{6}$ versus wetness trends: a prerollover zone with wetness of $>2.0 \%$ and a rollover zone with wetness of $<2.0 \%$ (Figure $6(\mathrm{a})$ ). Paleozoic gases from the South Jingbian and Yan'an fields are distributed mainly in the rollover zone, where $\delta^{13} \mathrm{C}-\mathrm{C}_{2} \mathrm{H}_{6}$ values become more negative with decreasing wetness. Upper Paleozoic gases from the Sulige, Shenmu, and Daniudi fields are distributed in the prerollover zone, where $\delta^{13} \mathrm{C}$ values of ethane become heavier with decreasing wetness (Figure $6(\mathrm{a})$ ). $\delta^{13} \mathrm{C}-\mathrm{C}_{2} \mathrm{H}_{6}$ rollover occurs with wetness of $<2.0 \%$ (this study), whereas for shale gases it occurs with wetness of $<5.0 \%$ [15]. A possible cause of this difference is that at the same maturity level, shale gases that originated from types I and II kerogen contain more wet gases than do coal-derived gases that originated from type III kerogen, owing to the different structures 


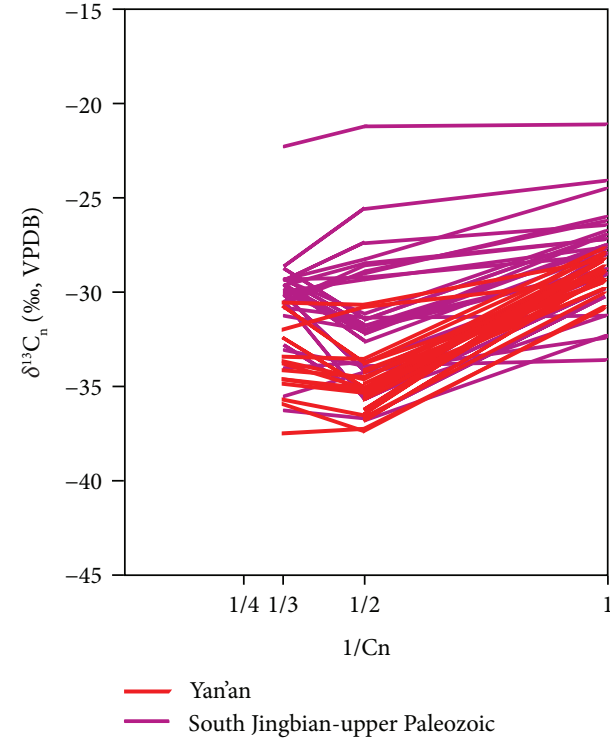

(a)

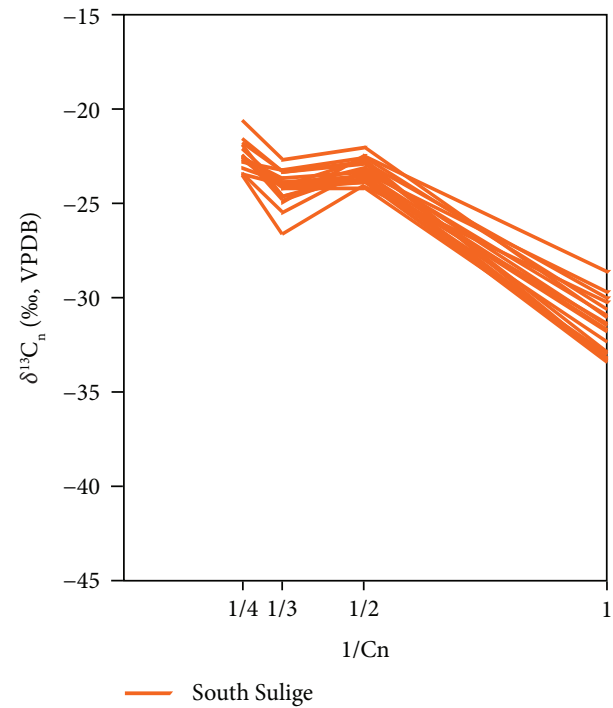

(c)

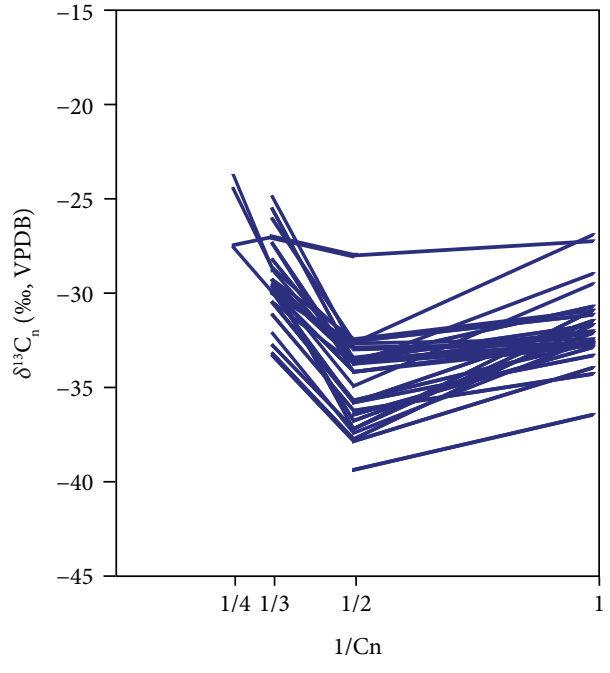

(b)

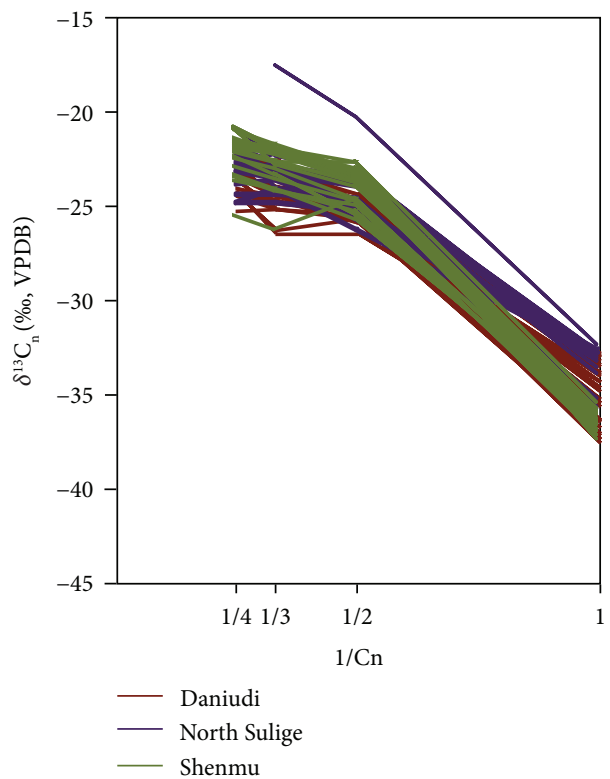

(d)

Figure 5: Carbon isotopic series of alkane gases in (a) Yan'an and upper Paleozoic South Jingbian gas fields; (b) lower Paleozoic South Jingbian field; (c) southern Sulige field; and (d) Daniudi, northern Sulige, and Shenmu gas fields.

TABLE 2: Relationship between maturity and carbon isotopic series in the Ordos Basin.

\begin{tabular}{|c|c|c|c|}
\hline Gas field & Source rock maturity & Carbon isotopic series & Detailed carbon isotopic series \\
\hline Yan'an/South Jingbian & $\mathrm{R}_{\mathrm{o}}>2.4 \%$ & Complete reversal & $\delta^{13} \mathrm{C}-\mathrm{CH}_{4}>\delta^{13} \mathrm{C}-\mathrm{C}_{2} \mathrm{H}_{6}>\delta^{13} \mathrm{C}-\mathrm{C}_{3} \mathrm{H}_{8}$ \\
\hline South Jingbian & $\mathrm{R}_{\mathrm{o}}>2.0 \%$ & Partial reversal & $\delta^{13} \mathrm{C}-\mathrm{CH}_{4}>\delta^{13} \mathrm{C}-\mathrm{C}_{2} \mathrm{H}_{6}<\delta^{13} \mathrm{C}-\mathrm{C}_{3} \mathrm{H}_{8}$ \\
\hline South Sulige & $\mathrm{R}_{\mathrm{o}}>2.0 \%$ & Partial reversal & $\delta^{13} \mathrm{C}-\mathrm{CH}_{4}<\delta^{13} \mathrm{C}-\mathrm{C}_{2} \mathrm{H}_{6}>\delta^{13} \mathrm{C}-\mathrm{C}_{3} \mathrm{H}_{8}$ \\
\hline North Sulige, Shenmu, and Daniudi & $\mathrm{R}_{\mathrm{o}}<2.0 \%$ & Positive series & $\delta^{13} \mathrm{C}-\mathrm{CH}_{4}<\delta^{13} \mathrm{C}-\mathrm{C}_{2} \mathrm{H}_{6}<\delta^{13} \mathrm{C}-\mathrm{C}_{3} \mathrm{H}_{8}$ \\
\hline
\end{tabular}

of parent sources. In the case of shale gas, the retained petroleum could closely contact the kerogen and/or source rock mineralogy, so the cracking rate of the crude oil is much ear- lier than the conventional gas formation [36]. The $\delta^{13} \mathrm{C}$ $\mathrm{C}_{2} \mathrm{H}_{6}$ content of Ordos gases increases with decreasing wetness (Figure 6(b)). 


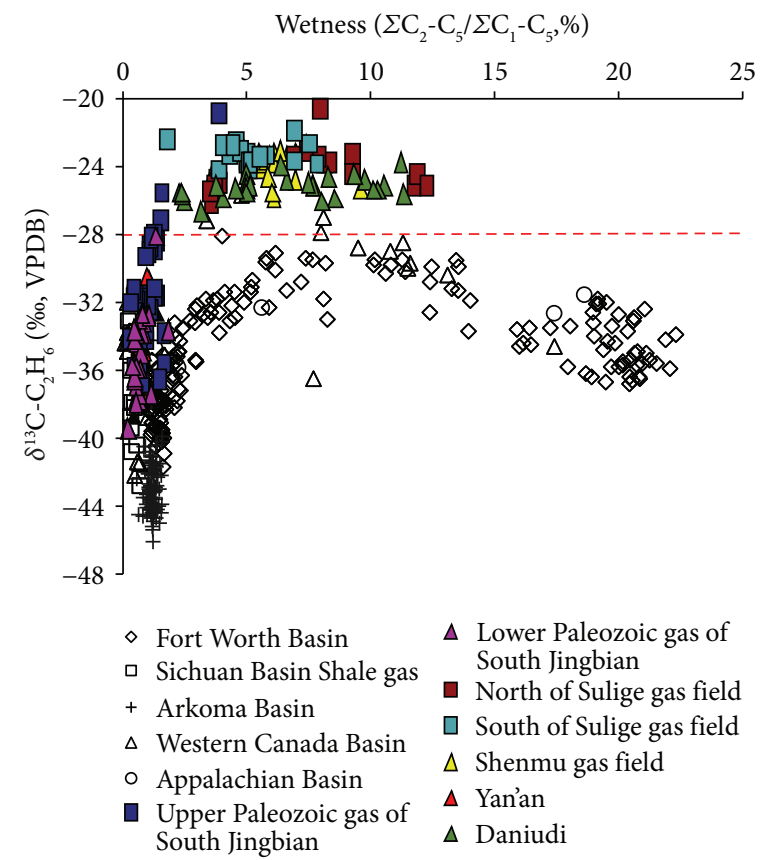

(a)

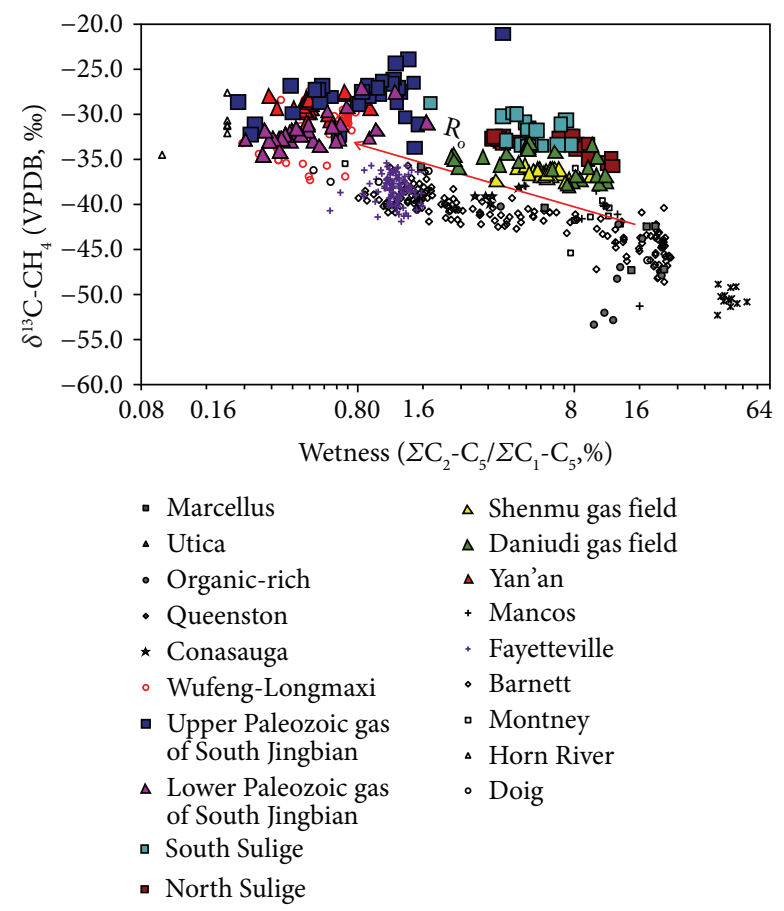

(b)

Figure 6: (a) $\delta^{13} \mathrm{C}-\mathrm{C}_{2} \mathrm{H}_{6}$ versus wetness (modified from [15]); (b) $\delta^{13} \mathrm{C}-\mathrm{CH}_{4}$ versus wetness (modified from [15]). (Data sources for shale gas in (a) and (b) are as follows: [13, 24-27, 29, 30]; from [14-16, 28, 31]).

\section{Discussion}

5.1. Source of Natural Gas. Numerous models have been proposed to identify the origin of hydrocarbon gases. One of the most widely used models is the Bernard diagram, which combines $\left(\mathrm{C}_{1} / \mathrm{C}_{2}+\mathrm{C}_{3}\right)$ and $\delta^{13} \mathrm{C}-\mathrm{CH}_{4}$ values. Whiticar [37] modified the diagram after Bernard et al. [38] and Faber and Stahl [39] to identify primary gases and gases altered by secondary effects. Based on previous work, Dai et al. [40] developed a similar model by plotting $\left(\mathrm{C}_{1} / \mathrm{C}_{2}+\mathrm{C}_{3}\right)$ versus $\delta^{13} \mathrm{C}-\mathrm{CH}_{4}$ values for natural gases with different origins from various basins in China, with the model being especially applicable for gas identification in China. A modified Dai plot (Figure 7) of the data in Table 1 reveals that most gases of the Sulige, Shenmu, and Daniudi fields are derived from type III kerogen coaly source rocks, supporting results of previous studies [16]. However, the source of Paleozoic gases in the southern Ordos Basin is more complicated. As shown in Figure 7, data for most upper Paleozoic South Jingbian and Yan'an gases plot in the field of "coal-type gas," whereas data for lower Paleozoic gases of South Jingbian plot in either the field of "cracking gas from oil and type II kerogen" or the field of "coal-type gas." This pattern indicates that the upper Paleozoic gas of the southern Ordos Basin is mainly coal-type gas derived from coaly source rocks, whereas the lower Paleozoic gas of the southern Ordos Basin is a mixture of coal-type gas and oil-type gas.

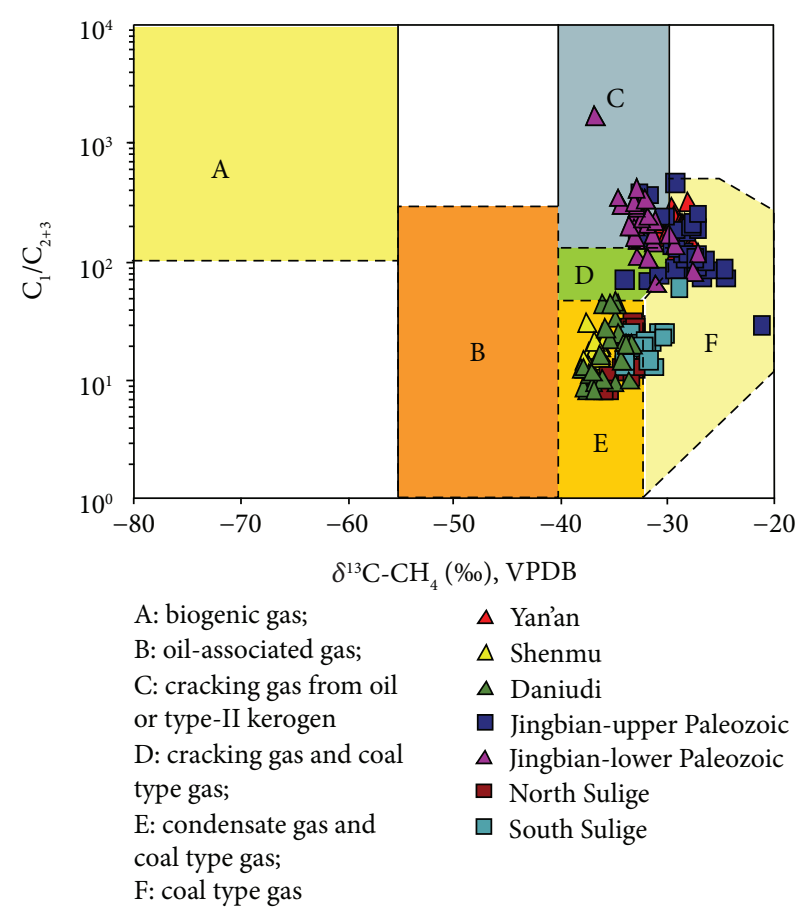

Figure 7: Plot of $\mathrm{C}_{1} / \mathrm{C}_{2-3}$ ratio versus $\delta^{13} \mathrm{C}-\mathrm{CH}_{4}$ (modified after [38-40]). 


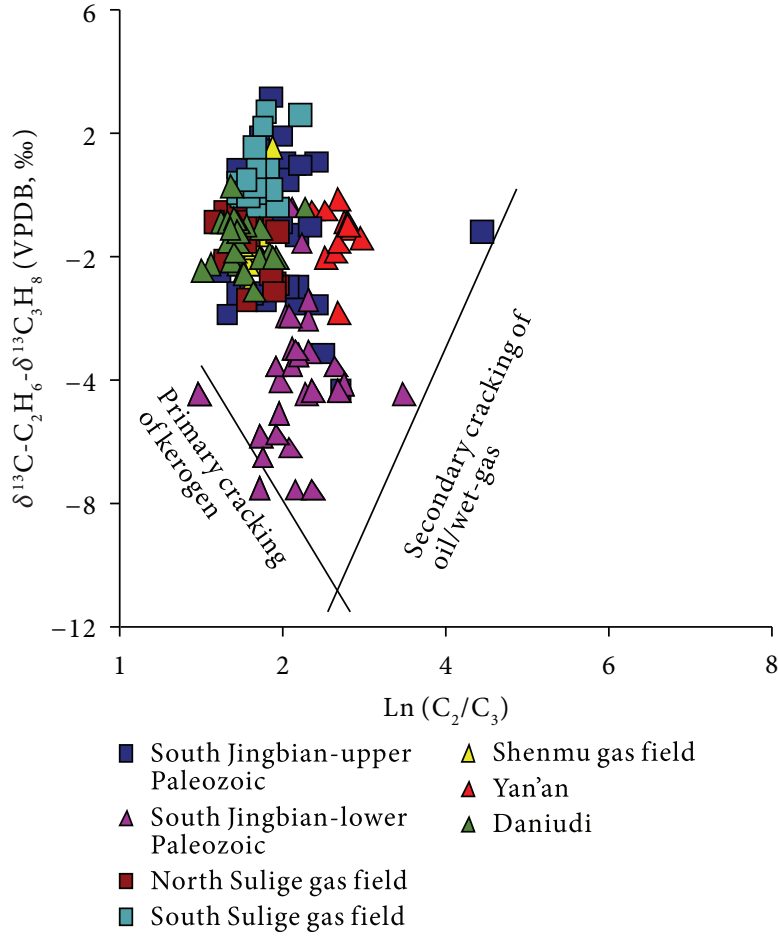

(a)

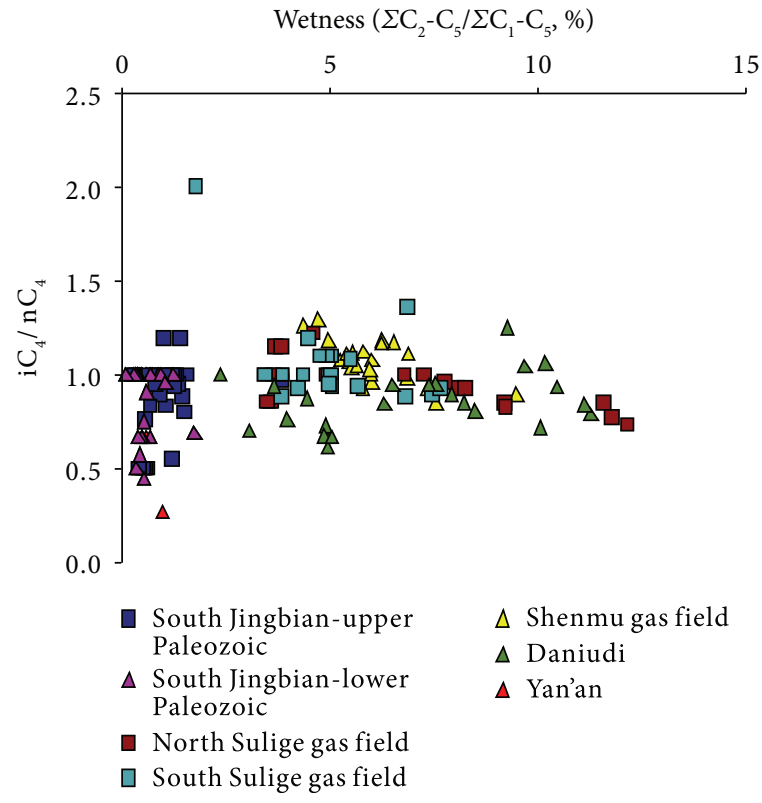

(b)

Figure 8: (a) Relationship between $\delta^{13} \mathrm{C}-\mathrm{C}_{2} \mathrm{H}_{6}-\delta^{13} \mathrm{C}-\mathrm{C}_{3} \mathrm{H}_{8}$ and gas wetness (the trending line for primary cracking and secondary cracking was modified from [44]); (b) relationship between $\mathrm{iC}_{4} / \mathrm{nC}_{4}$ and gas wetness (modified from [44]).

\subsection{Origin of Carbon Isotopic Reversals}

5.2.1. Possible Causes for the Carbon Isotopic Reversals. There are four possible causes of carbon isotopic reversal as follows.

(1) Inorganic Origin. Inorganic gases are formed by FischerTropsch synthesis when mantle degassing releases $\mathrm{CO}_{2}$ or $\mathrm{CO}$, forming hydrocarbons by reduction with reversed carbon isotopic compositions [41]. Such gases are typically characterized by $\delta^{13} \mathrm{C}-\mathrm{CH}_{4}>\delta^{13} \mathrm{C}-\mathrm{C}_{2} \mathrm{H}_{6}>\delta^{13} \mathrm{C}-\mathrm{C}_{3} \mathrm{H}_{8}>\delta^{13} \mathrm{C}-$ $\mathrm{C}_{4} \mathrm{H}_{10}$, with $\delta^{13} \mathrm{C}-\mathrm{CH}_{4}>-25 \%$ o [42]. Of the 107 Paleozoic gas samples from the southern Ordos Basin, 15 have complete carbon isotope reversal $\left(\delta^{13} \mathrm{C}-\mathrm{CH}_{4}>\delta^{13} \mathrm{C}-\mathrm{C}_{2} \mathrm{H}_{6}>\right.$ $\delta^{13} \mathrm{C}-\mathrm{C}_{3} \mathrm{H}_{8}$ ), whereas others have partial reversal with $\delta^{13} \mathrm{C}$ $\mathrm{CH}_{4}>\delta{ }^{13} \mathrm{C}-\mathrm{C}_{2} \mathrm{H}_{6}<\delta^{13} \mathrm{C}-\mathrm{C}_{3} \mathrm{H}_{8}$, or there are no $\delta^{13} \mathrm{C}-\mathrm{C}_{3} \mathrm{H}_{8}$ data (Table 1). The $\delta^{13} \mathrm{C}^{-\mathrm{CH}_{4}}$ value is less than $-25 \%$ o for all except three samples. As the ${ }^{3} \mathrm{He} /{ }^{4} \mathrm{He}$ value of mantle helium is higher than that of crust-sourced helium, the ratio $R / \mathrm{Ra}$, a comparison of the ${ }^{3} \mathrm{He} /{ }^{4} \mathrm{He}$ ratio of sample $(R)$ against the atmospheric ratio $(\mathrm{Ra})$, can be used to distinguish whether mantle-derived inorganic gas was injected into the natural gas-producing system [40]. Mantle-sourced helium in all cases has $R / \mathrm{Ra}$ ratios of $>0.1$ [42]. $R / \mathrm{Ra}$ values for gases in the southern Ordos are all $<0.1$. It is therefore concluded that the helium in the Paleozoic gases of the southern Ordos Basin is not mantle-derived, suggesting an "organic origin" of the associated hydrocarbon gases.

(2) Mixing. Some studies have suggested that the isotopic reversal observed in the southern Ordos Basin was caused by the mixing of coal-derived and oil-type gases from source rock containing type I-II kerogen [3], (Yang et al., 2012), $[4,7]$. This cause can easily be excluded. To generate gas mixtures with the light carbon isotopic composition of ethane, the oil-type gas end-member should have $\delta^{13} \mathrm{C}$ $\mathrm{C}_{2} \mathrm{H}_{6}$ lighter than the mixed gases. $\delta^{13} \mathrm{C}-\mathrm{C}_{2} \mathrm{H}_{6}$ values of most samples are less than $-32 \%$, with the lightest being $-39.42 \%$ o (Table 1); however, the lightest $\delta^{13} \mathrm{C}-\mathrm{C}_{2} \mathrm{H}_{6}$ values of oil-type gases found in Paleozoic reservoirs range from $-30.0 \%$ to $-32.0 \%$ o $[10,43]$. Even with all of the ethane in the mixture being oil-type gas, it would not account for the carbon isotopic characteristics observed here.

(3) Wet-Gas Cracking. This model involves the mixing of primary gas generated directly from kerogen cracking and secondary gas generated from intermediate kerogen products. The wet-gas cracking model produces a positive relationship between $\ln \left(\mathrm{C}_{2} / \mathrm{C}_{3}\right)$ and $\delta^{13} \mathrm{C}-\mathrm{C}_{2} \mathrm{H}_{6}-\delta^{13} \mathrm{C}-\mathrm{C}_{3} \mathrm{H}_{8}$ with increasing thermal stress [44] during the secondary cracking process and an initial increase followed by a rapid decrease in iso-butane/n-butane $\left(\mathrm{iC}_{4} / \mathrm{nC}_{4}\right)$ ratios with respect to the decrease in wetness (due to the lower stability of $\mathrm{iC}_{4}$ than $\mathrm{nC}_{4}$ at high maturity; [15]). The relationship between $\ln \left(\mathrm{C}_{2} / \mathrm{C}_{3}\right)$ and $\delta^{13} \mathrm{C}-\mathrm{C}_{2} \mathrm{H}_{6}-\delta^{13} \mathrm{C}-\mathrm{C}_{3} \mathrm{H}_{8}$ in the Ordos data (Figure $8(\mathrm{a})$ ) indicates that secondary cracking of wet gas does not occur in gases of the southern Ordos Basin. If cracking was the main cause of isotopic reversal, the trend of $\ln \left(\mathrm{C}_{2} / \mathrm{C}_{3}\right)$ would be expected to first decrease and then increase with increasing $\delta^{13} \mathrm{C}-\mathrm{C}_{2} \mathrm{H}_{6}-\delta^{13} \mathrm{C}-\mathrm{C}_{3} \mathrm{H}_{8}$, as shown for Barnett and Fayetteville shale gases [44]. This trend is 
not evident here (Figure 8(a)), indicating that wet-gas cracking cannot be the main cause of carbon isotopic reversal in the southern Ordos Basin. There is no obvious rollover pattern of $\mathrm{iC}_{4} / \mathrm{nC}_{4}$ versus wetness in Ordos Basin data (Figure 8(b)), suggesting that cracking of wet gas may have occurred.

(4) Abiotic Polymerization. Under conditions of ultrahigh temperatures and pressures, similar to those at which inorganic gases are generated, polymerization processes could alter carbon isotope distributions to be similar to those of inorganic gases [45]. If abiotic polymerization occurred, carbon isotopic separation of $1000 \ln \left(\sigma_{\mathrm{C} 2-\mathrm{C} 1}\right)$ would be expected to decrease as thermal stress increased. As more wet gases were polymerized with increasing thermal stress, wetness would be expected to increase. Taking $1000 \ln \left(\sigma_{\mathrm{C} 2-\mathrm{C} 1}\right)$ as an indicator of thermal stress, the dryness indicator $\mathrm{C}_{1} /\left(\mathrm{C}_{2}+\mathrm{C}_{3}\right)$ should decrease with decreasing $1000 \ln \left(\sigma_{\mathrm{C} 2-\mathrm{C} 1}\right)$ if the gases were generated by polymerization. Zeng et al. [45] suggested that gases from the Songliao field with isotopic reversals were generated by abiotic polymerization, and the trend for their data is plotted in Figure 9 for comparison. As shown in Figure 9, there is an initial increase and then decrease of $\mathrm{C}_{1} /\left(\mathrm{C}_{2}+\mathrm{C}_{3}\right)$ ratios with increasing $1000 \ln \left(\sigma_{\mathrm{C} 2-\mathrm{C} 1}\right)$ values for the Songliao gases. However, for data from the present study, $\mathrm{C}_{1} /\left(\mathrm{C}_{2}+\mathrm{C}_{3}\right)$ ratios of Ordos Basin gases continue to increase with increasing $1000 \ln \left(\sigma_{\mathrm{C} 2-\mathrm{C} 1}\right)$ (Figure 9$)$. If the gas had been generated by polymerization, $\mathrm{C}_{1} /\left(\mathrm{C}_{2}+\mathrm{C}_{3}\right)$ ratios should decrease in the high-maturity stage. Abiotic polymerization thus cannot be the main cause of carbon isotopic reversal in gases of the southern Ordos Basin.

Other models have been proposed to explain carbon isotopic reversal in overmature shale gases, including mass transport [46], water-kerogen redox reactions $[47,48]$, and other reactions involving transition metals [13, 49]. However, as southern Ordos Basin gases are stored in organicpoor sandstone and carbonates, fractionation through gas movement is unlikely to be the main cause of isotopic reversal. Nor could the other reactions be the cause because the conditions required for these reactions do not occur in the Ordos Basin.

5.2.2. Closed-System Aromatization-Polycondensation Model. It is clear that geological conditions should be taken into account in explaining carbon isotopic reversal of southern Ordos Basin gases. Dieckmann et al. [50] conducted closedsystem pyrolysis experiments with a type III kerogen Taglu Sequence sample, demonstrating that large amounts of gas are generated at extreme levels of thermal stress, with $\delta^{13} \mathrm{C}$ values of methane falling to values $10 \%$ lighter than those of open systems. They suggested that neoformed materials produced during low-maturity stages become active at high maturities $\left(\mathrm{R}_{\mathrm{o}}>2.5 \%\right)$ and recombine with residual kerogen or coal to form gases through aromatizationpolycondensation reactions. Furthermore, Erdmann and Horsfield [51] have shown that closed-system pyrolysis of type II/III kerogen of the heater formation results in recombination reactions, which act as sources of gas beyond the

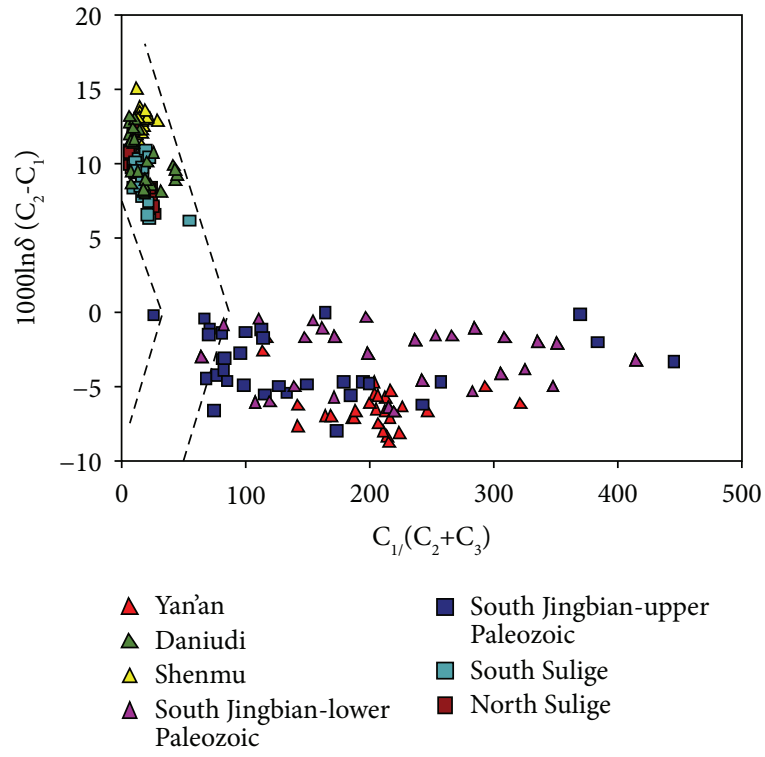

Figure 9: Plot of isotopic separation $1000 \ln \left(\sigma_{\mathrm{C} 2-\mathrm{C} 1}\right)$ versus $\mathrm{C}_{1} /$ $\left(\mathrm{C}_{2}+\mathrm{C}_{3}\right)$, where $\sigma_{\mathrm{C} 2-\mathrm{C} 1}=\left(1000+\delta^{13} \mathrm{C}-\mathrm{C}_{2} \mathrm{H}_{6}\right) /\left(1000+\delta^{13} \mathrm{C}-\mathrm{CH}_{4}\right)$ (modified after Zeng et al., 2008, the dashed line indicated the expected trend for gas generated by abiotic polymerization).

normal thermal conditions of oil-to-gas cracking, with aromatic compounds, phenols, and short n-alkyl chains being the main products formed from type III kerogen. Aromatization-polycondensation reactions are well known as major processes taking place during coal maturation [52-54]. In the mechanism proposed by Dieckmann et al. [50] and Erdmann and Horsfield [51], some neoformed macromolecules with relatively light carbon isotopic compositions were generated in low-maturity stages and preserved in the closed system. In overmature stages, these neoformed macromolecules react with residual kerogen or coal to form short-chain alkanes depleted in ${ }^{13} \mathrm{C}$. Such reactions could generate alkanes with light carbon isotopic compositions in the overmature stage.

Mahlstedt and Horsfield [36] showed that the results of Dieckmann et al. [50] and Erdmann and Horsfield [51] were applicable to natural maturation and also discovered that the ability of source rocks to generate late gas (the gas generated through aromatization-polycondensation at high maturity) is related to the initial organic-matter structure, depositional environment, and precursor biota. The heterogeneous aromatic and/or phenolic type II/III and type III coals from fluvial-deltaic-terrestrial environments are most favourable for late gas generation (Yang et al., 2015). The C-P source rock of the Ordos Basin contains Shanxi $\left(\mathrm{P}_{1} \mathrm{~s}\right)$, Taiyuan $\left(\mathrm{P}_{1} \mathrm{t}\right)$, and Benxi $\left(\mathrm{C}_{2} \mathrm{~b}\right)$ coals and mudstones, with these coaly source rocks having been precipitated in such an environment, with the shore and shallow water delta environment gradually transitioning to a tidal flat or terrestrial swamp. Over long periods, large areas of coal seam sediment were formed. The maceral composition of the source rocks includes vitrinite (Table 3 ), indicating a terrestrial origin. The sedimentary environment of the upper Paleozoic source 
TABLE 3: Geochemical parameters of upper Paleozoic source rocks of Ordos Basin $[55,56]$.

\begin{tabular}{|c|c|c|c|c|c|c|c|}
\hline \multirow{3}{*}{ Item } & & \multirow{3}{*}{$\begin{array}{c}\text { Organic } \\
\text { carbon (\%) }\end{array}$} & \multirow{3}{*}{$\begin{array}{c}\text { Chloroform } \\
\text { bitumen A (\%) }\end{array}$} & \multirow{3}{*}{$\begin{array}{c}\text { Total hydrocarbon (ppm) } \\
\text { Max/min } \\
\text { Average }\end{array}$} & \multicolumn{3}{|c|}{ Maceral composition (\%) } \\
\hline & & & & & Vitrinite & Fusinite & Inertinite \\
\hline & & & & & & & \\
\hline \multirow{4}{*}{ Shanxi formation } & \multirow{2}{*}{ Coal } & $89.17 / 49.28$ & $2.45 / 0.1$ & $6699.93 / 519.9$ & $90.2 / 43.8$ & $54 / 6.3$ & $12.3 / 0$ \\
\hline & & 73.6 & 0.8 & 2539.8 & 73.6 & 24 & 4.6 \\
\hline & \multirow{2}{*}{ Mudstone } & $19.29 / 0.07$ & $0.5 / 0.0024$ & $524.96 / 519.85$ & $47 / 8$ & $87 / 51.8$ & $20.3 / 0$ \\
\hline & & 2.25 & 0.04 & 163.8 & 20.5 & 72 & 7.4 \\
\hline \multirow{5}{*}{ Taiyuan formation } & \multirow{2}{*}{ Coal } & $83.2 / 3.83$ & $1.96 / 0.03$ & $4463 / 222$ & $98.8 / 21.2$ & $63.7 / 1.3$ & $15.1 / 0$ \\
\hline & & 74.7 & 0.61 & 1757.1 & 64.2 & 32.1 & 3.7 \\
\hline & \multirow{2}{*}{ Mudstone } & $23.38 / 0.1$ & $2.95 / 0.003$ & $1904.64 / 15$ & $82 / 8.3$ & $89.3 / 15.3$ & $34.5 / 0.3$ \\
\hline & & 3.33 & 0.12 & 361.6 & 38 & 53.3 & 8.4 \\
\hline & Limestone & $\begin{array}{c}6.29 / 0.11 \\
1.41\end{array}$ & $\begin{array}{c}0.43 / 0.0026 \\
0.08\end{array}$ & $\begin{array}{c}2194.53 / 88.92 \\
493.2\end{array}$ & & & \\
\hline \multirow{4}{*}{ Benxi formation } & \multirow{2}{*}{ Coal } & $80.26 / 55.38$ & $0.97 / 0.41$ & & $93.3 / 72$ & $25.2 / 6.7$ & $2.8 / 0$ \\
\hline & & 70.8 & 0.77 & & 87.2 & 16 & 1.4 \\
\hline & \multirow{2}{*}{ Mudstone } & $11.71 / 0.05$ & $0.44 / 0.0024$ & $1466.34 / 12.51$ & $47.8 / 12.3$ & $59.8 / 12.3$ & $39.5 / 0.3$ \\
\hline & & 2.54 & 0.065 & 322.73 & 24.5 & 44 & 18.2 \\
\hline
\end{tabular}

Note: this table has also been used in Liu et al., [57].

rocks indicates that they were favourable precursors for late gas generation.

The geological setting of the southern Ordos Basin provides conditions similar to those essential for such reactions, including type III coaly source rock, high thermal maturity, and a closed system. Most southern Ordos Basin gases were formed from thick coaly source rocks with high maturities and high quality. Large amounts of gas were generated in short time periods and stored in nearby tight sandstone reservoirs with thick caprocks and with gas migration being hindered by the stable basement. Paleozoic gas thus accumulated near its source. Therefore, southern Ordos Basin gas fields have conditions approximating closed systems in which aromatization-polycondensation reactions may occur.

A special example for comparison is the gas of the Kela2 gas field in the Tarim Basin, which was also generated from overmature $\left(\mathrm{R}_{\mathrm{o}}>2.0 \%\right)$ coaly source rocks, but do not display carbon isotopic reversal [16], because the Kela2 gas field is an open system, with neoformed materials having expired before the overmature stage.

If aromatization-polycondensation reactions took place in the southern Ordos Basin gas fields under study here, the gases generated would contain isotopically light methane, ethane, and propane. However, as the amounts of methane $>$ ethane $>$ propane in the residual alkanes generated from kerogen cracking, a small addition of newly formed gas would result in rollover of $\delta^{13} \mathrm{C}-\mathrm{C}_{3} \mathrm{H}_{8}$, whereas rollover of $\delta^{13} \mathrm{C}^{-} \mathrm{CH}_{4}$ would require a larger amount. This would result in two trends: (1) with increasing maturity, rollover of $\delta^{13} \mathrm{C}_{-} \mathrm{C}_{3} \mathrm{H}_{8}$ would occur first, followed by $\delta^{13} \mathrm{C}-\mathrm{C}_{2} \mathrm{H}_{6}$, and although isotopically light $\mathrm{C}_{1}$ was added, residual heavy $\mathrm{C}_{1}$ would dominate the gas mixture with insignificant changes in $\delta^{13} \mathrm{C}_{-} \mathrm{CH}_{4}$, and rollover of $\delta^{13} \mathrm{C}_{-}-\mathrm{CH}_{4}$ would occur last; (2) as ${ }^{13} \mathrm{C}_{3}$ became depleted more rapidly than ${ }^{13} \mathrm{C}_{1}$ and ${ }^{13} \mathrm{C}_{2}$, reversal of $\delta^{13} \mathrm{C}-\mathrm{C}_{2} \mathrm{H}_{6}$ and $\delta^{13} \mathrm{C}-\mathrm{C}_{3} \mathrm{H}_{8}$ would occur first, with reversal of $\delta^{13} \mathrm{C}^{-} \mathrm{CH}_{4}$ and $\delta^{13} \mathrm{C}_{-} \mathrm{C}_{2} \mathrm{H}_{6}$ occurring later.
The evolution of carbon isotopic compositions in Ordos Basin gas fields appears to follow these two processes (Figures 6(a), 6(b) and 10(a)). The rollover points of $\delta^{13} \mathrm{C}$ $\mathrm{CH}_{4}, \delta^{13} \mathrm{C}-\mathrm{C}_{2} \mathrm{H}_{6}$, and $\delta^{13} \mathrm{C}-\mathrm{C}_{3} \mathrm{H}_{8}$ occur at different wetness and thermal maturities, with wetness of $\delta^{13} \mathrm{C}^{-} \mathrm{CH}_{4}, \delta^{13} \mathrm{C}$ $\mathrm{C}_{2} \mathrm{H}_{6}$, and $\delta^{13} \mathrm{C}_{-} \mathrm{C}_{3} \mathrm{H}_{8}$ being $1.2 \%, 2.0 \%$, and $5.0 \%$, respectively (Figures 6(a), 10(a) and 10(b)). With respect to increasing maturity in the whole basin, the reversal of $\delta^{13} \mathrm{C}-\mathrm{C}_{3} \mathrm{H}_{8}<\delta^{13} \mathrm{C}-\mathrm{C}_{2} \mathrm{H}_{6}$ occurs first in the south Sulige field $\left(\mathrm{R}_{\mathrm{o}} 2.0 \%-2.6 \%\right)$, then reversal of $\delta^{13} \mathrm{C}-\mathrm{C}_{2} \mathrm{H}_{6}<\delta^{13} \mathrm{C}$ $\mathrm{CH}_{4}$ occurs in the South Jingbian field $\left(2.0 \%<\mathrm{R}_{\mathrm{o}}<3.8 \%\right)$, whereas complete reversal occurs only where $\mathrm{R}_{\mathrm{o}}>2.4 \%$.

5.3. Hydrogen Isotopic Reversal. A unique characteristic of the southern Ordos Basin gas fields is the hydrogen isotopic reversal $\left(\delta \mathrm{D}-\mathrm{CH}_{4}>\delta \mathrm{D}-\mathrm{C}_{2} \mathrm{H}_{6}\right)$. Rollover of $\delta \mathrm{D}-\mathrm{CH}_{4}$ has been observed in overmature shale gases worldwide [13-15]. Although southern Ordos Basin gases show a rollover of $\delta \mathrm{D}-\mathrm{C}_{2} \mathrm{H}_{6}$ (Figure 11(a)), Figure $11(\mathrm{~b})$ indicates that $\delta \mathrm{D}$ $\mathrm{CH}_{4}$ values continue to increase as wetness decreases, which differs from the trend observed for overmature shale gases, although both gas types display hydrogen isotopic reversal $\left(\delta \mathrm{D}-\mathrm{CH}_{4}>\delta \mathrm{D}-\mathrm{C}_{2} \mathrm{H}_{6}\right)$.

The hydrogen isotopic reversal of methane has been reported in overmature unconventional and conventional gases [13-15]. The temperature of the reservoirs can reach $200-350^{\circ} \mathrm{C}$, and at such temperatures, hydrocarbon reactions can be impacted by the presence of water [47] and redoxactive transition metals [58]. Most previous studies attributed the phenomenon to isotopic exchange between $\mathrm{CH}_{4}$ and $\mathrm{H}_{2} \mathrm{O}$ at high temperatures, leading to reversal of $\delta \mathrm{D}$ $\mathrm{CH}_{4}$ and $\delta \mathrm{D}-\mathrm{C}_{2} \mathrm{H}_{6}$ and rollover of $\delta \mathrm{D}-\mathrm{CH}_{4}$ with increasing maturity. Gases that have undergone isotopic exchange between $\mathrm{CH}_{4}$ and $\mathrm{H}_{2} \mathrm{O}$ can be recognized by increasing $\mathrm{CO}_{2}$ content with decreasing wetness and decreasing $\delta^{13} \mathrm{C}$ $\mathrm{CO}_{2}$ with decreasing wetness [15]. 


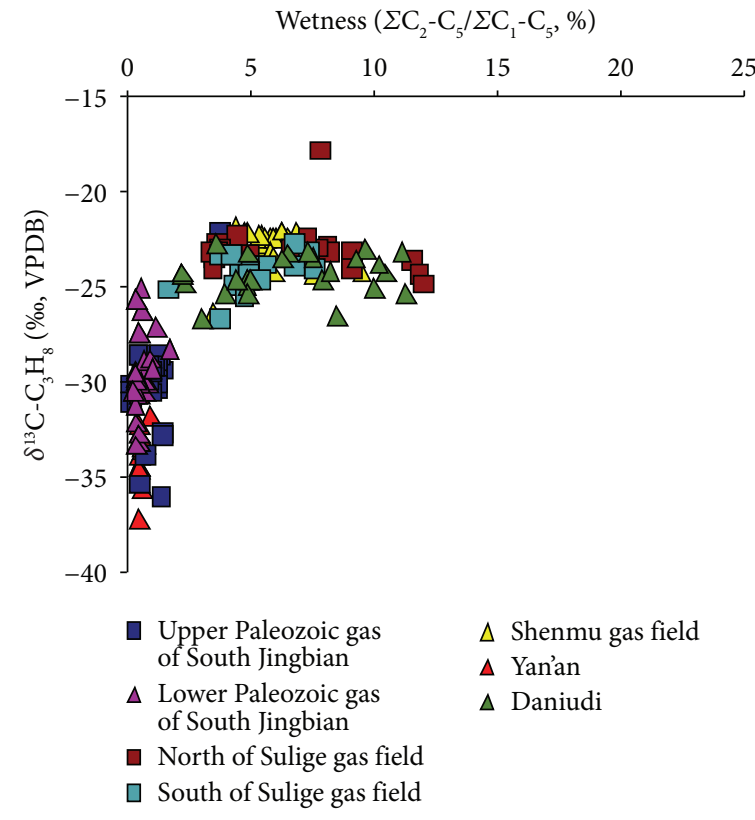

(a)

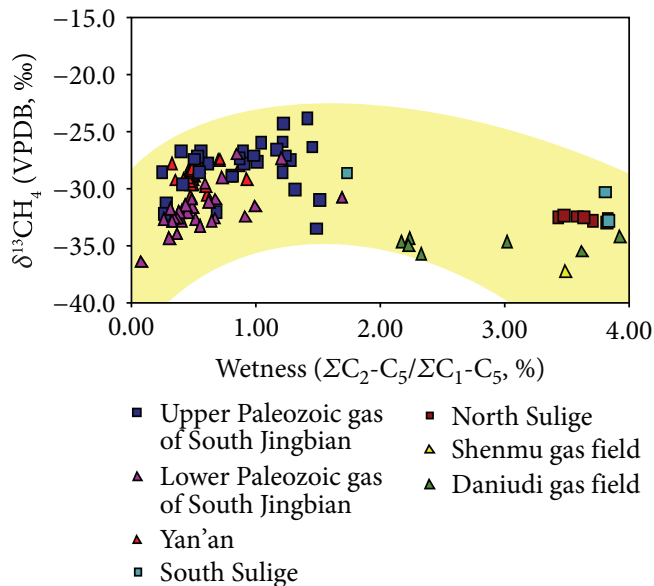

(b)

Figure 10: (a) $\delta^{13} \mathrm{C}-\mathrm{C}_{3} \mathrm{H}_{8}$ versus gas wetness (modified from [15]); (b) detailed plot of $\delta^{13} \mathrm{C}-\mathrm{CH}_{4}$ versus gas wetness with a wetness range of $0 \%-4 \%$.

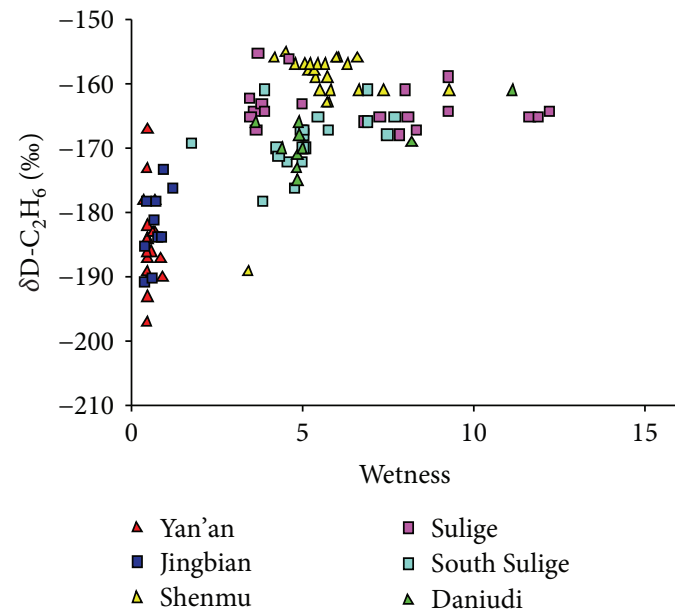

(a)

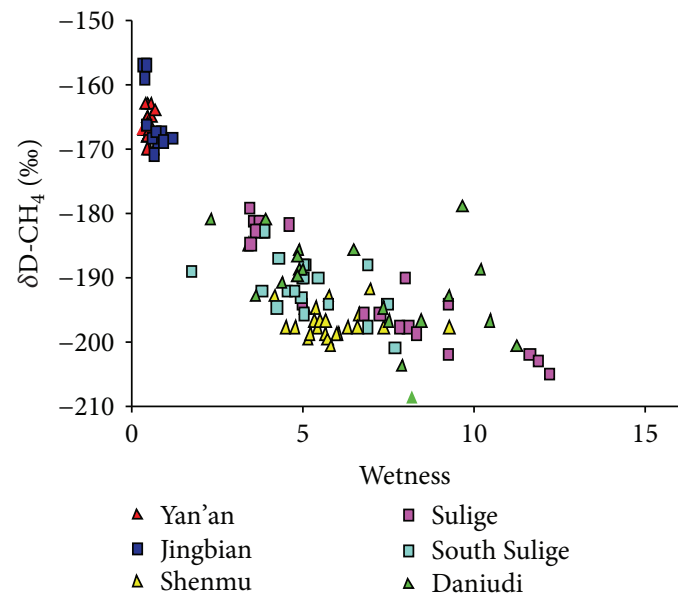

(b)

Figure 11: (a) $\delta \mathrm{D}-\mathrm{C}_{2} \mathrm{H}_{6}$ versus wetness of the gases from different gas fields in the Ordos Basin; (b) $\delta \mathrm{D}-\mathrm{CH}_{4}$ versus wetness of the gases from different gas fields in the Ordos Basin.

Evolutionary trends of $\mathrm{CO}_{2}$ content and $\delta^{13} \mathrm{C}-\mathrm{CO}_{2}$ with decreasing wetness are illustrated in Figure 12. $\mathrm{CO}_{2}$ contents of southern Ordos Basin gases are higher than those of other gases in the Ordos Basin (Figure 12(a)), but there is no apparent relationship between $\delta^{13} \mathrm{C}-\mathrm{CO}_{2}$ and wetness (Figure 12(b)). Figure 3(b) indicates that $\mathrm{CO}_{2}$ is of inorganic origin, and its $\delta^{13} \mathrm{C}-\mathrm{CO}_{2}$ values are much heavier than those of overmature shale gases. These factors indicate that the high $\mathrm{CO}_{2}$ contents were not generated from reactions of $\mathrm{CH}_{4}$ and $\mathrm{H}_{2} \mathrm{O}$, and isotopic exchange between $\mathrm{CH}_{4}$ and $\mathrm{H}_{2} \mathrm{O}$ at high temperatures cannot be the cause of hydrogen isotopic reversal in the southern Ordos Basin. Moreover, recent work on the clumped isotopic composition of methane indicates that all hydrogen atoms in methane (and ethane and propane) are from organic matter and that a contribution of hydrogen from water is unlikely [59].

The main difference between the hydrogen isotopic compositions of southern Ordos Basin gases and other overmature gases is that rollover of hydrogen isotopes in the former occurs with $\delta \mathrm{D}-\mathrm{C}_{2} \mathrm{H}_{6}$ whereas the latter occurs with $\delta \mathrm{D}-\mathrm{CH}_{4}$. This is attributed to simultaneous rollover of carbon and hydrogen isotopes (i.e., both carbon and 


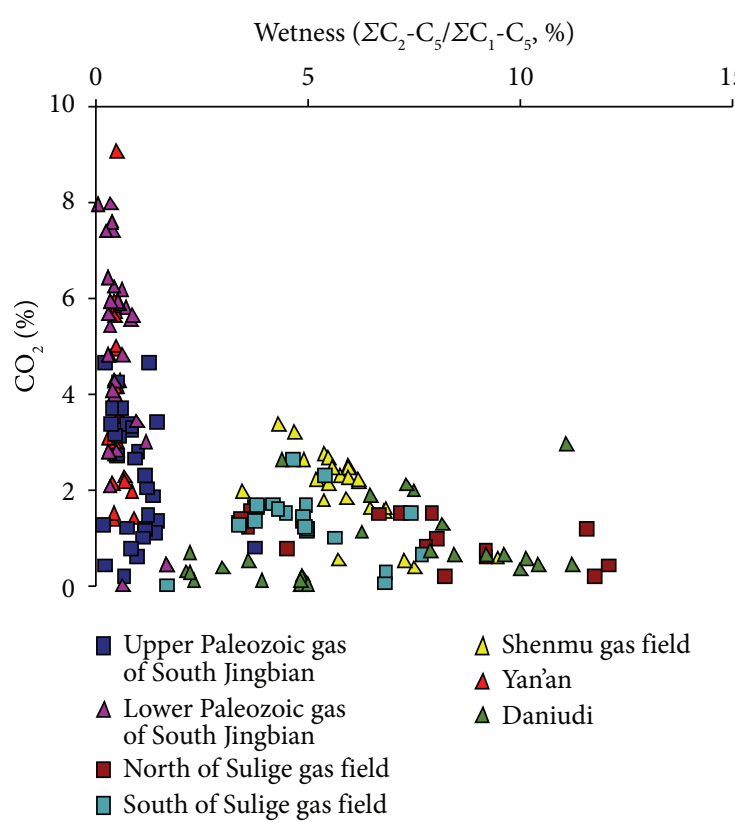

(a)

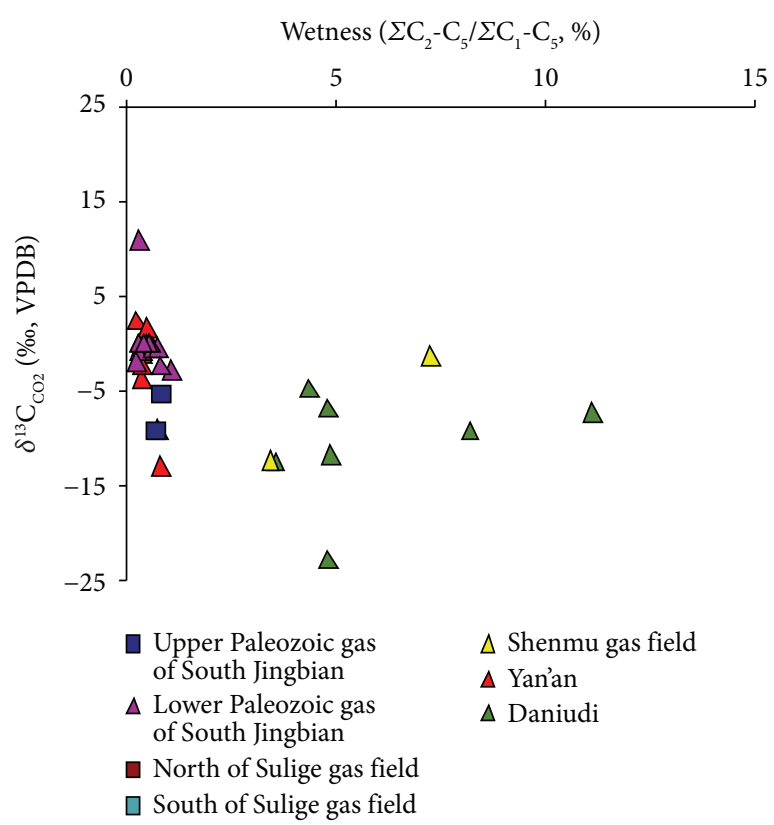

(b)

Figure 12: (a) $\mathrm{CO}_{2}$ content versus wetness (modified from [15]); (b) $\delta^{13} \mathrm{C}-\mathrm{CO}_{2}$ versus wetness (modified from [15]).

hydrogen isotopes of methane continue increasing with maturity, whereas those of ethane increase at first and then decrease, indicating that the rollover of carbon and hydrogen isotopes occur through the same process, possibly at the same time).

In the late gas-generation stage, when the first formed moieties recombined with residual kerogen to form methane and ethane, the process should have followed a similar isotopic fractionation rule to that of primary gas generation. That is, the ${ }^{12} \mathrm{C}-{ }^{12} \mathrm{C}$ bonds in all $\mathrm{C}^{-}{ }^{1} \mathrm{H}$ molecules have lower activation energy (are easier to break) than those in molecules containing at least one ${ }^{2} \mathrm{H}$, and the remaining reactants (the residual kerogen) become ${ }^{2} \mathrm{H}$-enriched, whereas the gas products become ${ }^{2} \mathrm{H}$-depleted [60]. In the late gas-generation stage, the cracking of earlier-generated $\mathrm{C}_{6+}$ moieties would have released alkanes with lighter hydrogen isotopic compositions than those of alkanes originating from late kerogen. These gases with light hydrogen isotopes mixed with the existing gases with much heavier hydrogen isotopes, causing the isotopic rollover of ethane. As the amount of ethane was much smaller than that of methane, a small amount of mixing would have easily caused the hydrogen isotopic composition of the mixed ethane to be lighter, resulting in the rollover. This is consistent with the recent work of $\mathrm{Ni}$ et al. [61].

\section{Conclusions}

(1) Paleozoic natural gases in the southern Ordos Basin display carbon isotopic reversals, and the gases are not of inorganic origin. Modelled carbon isotope trends of mixed gases containing varying proportions of oil-type and coal-derived gases show that carbon isotopic reversals are not caused by the mixing of different types of gases. Moreover, because of the different geological setting between conventional coal-derived gas and unconventional shale gas, the mechanisms for carbon isotopic reversal in shale gas could not be applied to explain the reversal in southern Ordos gases. The wetness of southern Ordos gases decreases rather than increases with incremental increases in thermal stress, indicating that abiotic polymerization was not the cause of the carbon isotopic reversal

(2) Given the evolutionary trend of $\delta^{13} \mathrm{C}-\mathrm{CH}_{4}, \delta^{13} \mathrm{C}$ $\mathrm{C}_{2} \mathrm{H}_{6}$, and $\delta^{13} \mathrm{C}-\mathrm{C}_{3} \mathrm{H}_{8}$ and the geological background of the southern Ordos Basin, carbon isotopic reversal in southern Ordos gases is best explained by a closedsystem aromatization-polycondensation model, during which some neoformed macromolecules with relatively light carbon isotopic compositions were generated at a low-maturity stage and preserved in the closed system. During the overmature stage, these neoformed macromolecules reacted with the residual kerogen/coal structure to form short-chain alkanes depleted in ${ }^{13} \mathrm{C}$ through aromatizationpolycondensation reactions. The evolutionary trend of $\delta \mathrm{D}-\mathrm{CH}_{4}$ and $\delta \mathrm{D}-\mathrm{C}_{2} \mathrm{H}_{6}$ in the Ordos Basin also suggests that the hydrogen isotopic reversal was caused by aromatization-polycondensation reactions

\section{Data Availability}

The data used to support the findings of this study are included within the article. 


\section{Disclosure}

The manuscript has been presented at the 2019 Goldschmidt as a short abstract: https://goldschmidt.info/2019/abstracts/ abstractView? $\mathrm{id}=2019005642$.

\section{Conflicts of Interest}

The author declares no conflicts of interest.

\section{Acknowledgments}

The author thanks Professor W. Z. Zhang and Q. F. Kong of the Petroleum Exploration and Development Research Institute, Changqing Oilfield Company, PetroChina, for contributing data and supporting sample collection. The author also appreciates the careful reviews and constructive suggestions of the anonymous reviewers. This study was supported by the National Natural Science Foundation for Young Scientists of China (Grant No. 41702161).

\section{References}

[1] W. J. Stahl and B. D. Carey Jr., "Source-rock identification by isotope analyses of natural gases from fields in the Val Verde and Delaware basins, west Texas," Chemical Geology, vol. 16, no. 4, pp. 257-267, 1975.

[2] Y. Tang, J. K. Perry, P. D. Jenden, and M. Schoell, "Mathematical modeling of stable carbon isotope ratios in natural gases," Geochimica et Cosmochimica Acta, vol. 64, no. 15, pp. 26732687, 2000.

[3] A. P. Hu, J. Li, W. Z. Zhang, Z. S. Li, L. Hou, and Q. Y. Liu, "Geochemical characteristics and origin of gases from the Upper, Lower Paleozoic and the Mesozoic reservoirs in the Ordos Basin, China," Science in China Series D: Earth Sciences, vol. 51, no. S1, Supplement I, pp. 183-194, 2008.

[4] J. Dai, D. Gong, Y. Ni, C. Yu, and W. Wu, "Genetic types of alkane gases in giant gas fields with proven reserves over $1000 \times 10^{8} \mathrm{~m}^{3}$ in China," Energy Exploration \& Exploitation, vol. 32, no. 1, pp. 1-18, 2014.

[5] D. Gong, J. Li, I. Ablimit et al., "Geochemical characteristics of natural gases related to late Paleozoic coal measures in China," Marine and Petroleum Geology, vol. 96, pp. 474-500, 2018.

[6] C. Yu, S. P. Huang, D. Y. Gong, F. R. Liao, J. Li, and Q. W. Sun, "Partial reversal cause of carbon and hydrogen isotope compositions of natural gas: a case study in Sulige gas field, Ordos Basin," Acta Petrolei Sinica, vol. 34, Supplement 1, pp. 92101, 2013.

[7] J. Zhao, W. Zhang, J. Li, Q. Cao, and Y. Fan, "Genesis of tight sand gas in the Ordos Basin, China," Organic Geochemistry, vol. 74, pp. 76-84, 2014.

[8] J. X. Dai, Y. Y. Ni, S. P. Huang et al., "Origins of secondary negative carbon isotopic series in natural gas," Natural Gas Geoscience, vol. 27, no. 1, pp. 1-7, 2016.

[9] Z. Feng, D. Liu, S. Huang, D. Gong, and W. Peng, "Geochemical characteristics and genesis of natural gas in the Yan'an gas field, Ordos Basin, China," Organic Geochemistry, vol. 102, pp. 67-76, 2016.

[10] Q. F. Kong, W. Z. Zhang, J. F. Li, and C. L. Zan, "Origin of natural gas in Ordovician in the west of Jingbian Gasfield, Ordos Basin," Natural Gas Geoscience, vol. 21, no. 1, pp. 71-80, 2016.
[11] D. Liu, W. Zhang, Q. Kong, Z. Feng, C. Fang, and W. Peng, "Lower Paleozoic source rocks and natural gas origins in Ordos Basin, NW China," Petroleum Exploration and Development, vol. 43, no. 4, pp. 591-601, 2016.

[12] X. Xia, J. Chen, R. Braun, and Y. Tang, "Isotopic reversals with respect to maturity trends due to mixing of primary and secondary products in source rocks," Chemical Geology, vol. 339, pp. 205-212, 2013.

[13] R. C. Burruss and C. D. Laughrey, "Carbon and hydrogen isotopic reversals in deep basin gas: evidence for limits to the stability of hydrocarbons," Organic Geochemistry, vol. 41, no. 12, pp. 1285-1296, 2010.

[14] B. Tilley and K. Muehlenbachs, "Isotope reversals and universal stages and trends of gas maturation in sealed, selfcontained petroleum systems," Chemical Geology, vol. 339, pp. 194-204, 2013.

[15] J. Zumberge, K. Ferworn, and S. Brown, "Isotopic reversal ('rollover') in shale gases produced from the Mississippian Barnett and Fayetteville formations," Marine and Petroleum Geology, vol. 31, no. 1, pp. 43-52, 2012.

[16] J. X. Dai, C. N. Zou, and W. Li, Large Coal-Derived Gas Fields in China and Their Sources, Science Press, Beijing, 2014.

[17] H. Guoyi, L. Jin, S. Xiuqin, H. Zhongxi et al., "The origin of natural gas and the hydrocarbon charging history of the Yulin gas field in the Ordos Basin, China," International Journal of Coal Geology, vol. 81, no. 4, pp. 381-391, 2010.

[18] S. Huang, X. Fang, D. Liu, C. Fang, and T. Huang, "Natural gas genesis and sources in the Zizhou gas field, Ordos Basin, China," International Journal of Coal Geology, vol. 152, no. SI, pp. 132-143, 2015.

[19] S. Huang, C. Yu, D. Gong, W. Wu, and F. Liao, "Stable carbon isotopic characteristics of alkane gases in tight sandstone gas fields and the gas source in China," Energy Exploration \& Exploitation, vol. 32, no. 1, pp. 75-92, 2014.

[20] X. Wu, Q. Liu, J. Zhu et al., "Geochemical characteristics of tight gas and gas-source correlation in the Daniudi gas field, the Ordos Basin, China," Marine and Petroleum Geology, vol. 79, pp. 412-425, 2017.

[21] J. Dai, J. Li, X. Luo et al., "Stable carbon isotope compositions and source rock geochemistry of the giant gas accumulations in the Ordos Basin, China," Organic Geochemistry, vol. 36, no. 12, pp. 1617-1635, 2005.

[22] R. Yang, Z. He, G. Qiu, Z. Jin, D. Sun, and X. Jin, “A late Triassic gravity flow depositional system in the southern Ordos Basin," Petroleum Exploration and Development, vol. 41, no. 6, pp. 724-733, 2014.

[23] Z. He and C. Deng, "Discovery and exploration in Jingbian gas field of Ordos Basin," Marine Origin Petroleum Geology, vol. 10, no. 2, pp. 37-42, 2005.

[24] R. J. Hill, D. M. Jarvie, J. Zumberge, M. Henry, and R. M. Pollastro, "Oil and gas geochemistry and petroleum systems of the Fort Worth Basin," AAPG Bulletin, vol. 91, no. 4, pp. 445-473, 2007.

[25] R. C. Johnson and D. D. Rice, "Occurrence and geochemistry of natural gases, Piceance Basin, Northwest Colorado," AAPG Bulletin, vol. 77, pp. 980-998, 1990.

[26] A. M. Martini, L. M. Walter, and J. C. McIntosh, "Identification of microbial and thermogenic gas components from Upper Devonian black shale cores, Illinois and Michigan basins," AAPG Bulletin, vol. 92, no. 3, pp. 327339, 2008. 
[27] S. G. Osborn and J. C. McIntosh, "Chemical and isotopic tracers of the contribution of microbial gas in Devonian organic-rich shales and reservoir sandstones, northern Appalachian Basin," Applied Geochemistry, vol. 25, no. 3, pp. 456471, 2010.

[28] J. C. Pashin, M. R. McIntyre-Redden, S. D. Mann, D. C. Kopaska-Merkel, M. Varonka, and W. Orem, "Relationships between water and gas chemistry in mature coalbed methane reservoirs of the Black Warrior Basin," International Journal of Coal Geology, vol. 126, pp. 92-105, 2014.

[29] N. D. Rodriguez and R. P. Philp, "Geochemical characterization of gases from the Mississippian Barnett Shale, Fort Worth Basin, Texas," AAPG Bulletin, vol. 94, no. 11, pp. 1641-1656, 2010.

[30] D. Strąpoć, M. Mastalerz, A. Schimmelmann, A. Drobniak, and N. R. Hasenmueller, "Geochemical constraints on the origin and volume of gas in the New Albany Shale (Devonian-Mississippian), eastern Illinois Basin," AAPG Bulletin, vol. 94, no. 11, pp. 1713-1740, 2010.

[31] W. Wu, D. Dong, C. Yu, and D. Liu, "Geochemical characteristics of shale gas in Xiasiwan area, Ordos Basin," Energy Exploration \& Exploitation, vol. 33, no. 1, pp. 25-41, 2015.

[32] J. X. Dai and H. Qi, "Relationship of $\delta^{13} \mathrm{C}-\mathrm{R}_{\mathrm{o}}$ of coalderived gas in China," Chinese Science Bulletin, vol. 34, pp. 690-692, 1989.

[33] J. X. Dai, Y. Song, C. Dai, and D. Wang, "Geochemistry and accumulation of carbon dioxide gases in China," AAPG Bulletin, vol. 80, pp. 1615-1626, 1996.

[34] Q. Liu, M. Chen, W. Liu, J. Li, P. Han, and Y. Guo, "Origin of natural gas from the Ordovician paleo-weathering crust and gas-filling model in Jingbian gas field, Ordos Basin, China," Journal of Asian Earth Sciences, vol. 35, no. 1, pp. 74-88, 2009.

[35] J. Thrasher and A. J. Fleet, "Predicting the risk of carbon dioxide "pollution" in petroleum reservoirs," in Organic geochemistry: Developments and applications to energy, climate, environment and human history: Proceedings 17th International Meeting on Organic Geochemistry, pp. 1086-1088, San Sebastian, Spain, September 1995.

[36] N. Mahlstedt and B. Horsfield, "Metagenetic methane generation in gas shales I. Screening protocols using immature samples," Marine and Petroleum Geology, vol. 31, no. 1, pp. 27-42, 2012.

[37] M. J. Whiticar, "Stable isotope geochemistry of coals, humic kerogens and related natural gases," International Journal of Coal Geology, vol. 32, no. 1-4, pp. 191-215, 1996.

[38] B. B. Bernard, J. M. Brooks, and W. M. Sackett, "Light hydrocarbons in recent Texas continental shelf and slope sediments," Journal of Geophysical Research, vol. 83, no. C8, pp. 4053-4061, 1978.

[39] E. Faber and W. Stahl, "Geochemical surface exploration for hydrocarbons in North Sea," AAPG Bulletin, vol. 68, pp. 363-386, 1984.

[40] J. X. Dai, X. G. Pei, and H. F. Qi, China Natural Gas Geology, vol. 1, Petroleum Industry Press, Beijing, 1992.

[41] T. M. McCollom and J. S. Seewald, "Carbon isotope composition of organic compounds produced by abiotic synthesis under hydrothermal conditions," Earth and Planetary Science Letters, vol. 243, no. 1-2, pp. 74-84, 2006.

[42] P. D. Jenden, D. R. Hilton, I. R. Kaplan, and H. Craig, "Abiogenic hydrocarbons and mantle helium in oil and gas fields," in The Future of Energy Gases - USGS Professional
Paper 1570, D. G. Howell, Ed., pp. 31-56, United States Geological Survey, 1993.

[43] J. K. Mi, X. M. Wang, and G. Y. Zhu, "Origin determination of gas from Jingbian gas field in Ordos basin collective through the geochemistry of gas from inclusions and source rock pyrolysis," Acta Petrologica Sinica, vol. 28, no. 3, pp. 859-869, 2012.

[44] A. A. Prinzhofer and A. Y. Huc, "Genetic and post-genetic molecular and isotopic fractionations in natural gases," Chemical Geology, vol. 126, no. 3-4, pp. 281-290, 1995.

[45] H. Zeng, J. Li, and Q. Huo, "A review of alkane gas geochemistry in the Xujiaweizi fault-depression, Songliao Basin," Marine and Petroleum Geology, vol. 43, pp. 284-296, 2013.

[46] Q. R. Passey, K. M. Bohacs, W. L. Esch, R. Klimentidis, and S. Sinha, "From oil-prone source rock to gas-producing shale reservoir - geologic and petrophysical characterization of unconventional shale-gas reservoir," in Proceedings of International Oil and Gas Conference and Exhibition in China, Beijing, China, June 2010.

[47] M. D. Lewan, "Experiments on the role of water in petroleum formation," Geochimica et Cosmochimica Acta, vol. 61, no. 17, pp. 3691-3723, 1997.

[48] L. C. Price, “A possible deep-basin high-rank gas machine via water organic-matter redox reactions," in Geologic Studies of Deep Natural Gas Resources, T. S. Dyman and V. A. Kuuskraa, Eds., pp. H1-H29, USGS, Denver, 2001.

[49] Y. Tang and X. Y. Xia, "Quantitative assessment of shale gas potential based on its special generation and accumulation processes," in AAPG Convention and Exhibition of AAPG Search and Discovery Article \#90124, Houston, TX, USA, April 2011.

[50] V. Dieckmann, R. Ondrak, B. Cramer, and B. Horsfield, "Deep basin gas: new insights from kinetic modelling and isotopic fractionation in deep-formed gas precursors," Marine and Petroleum Geology, vol. 23, no. 2, pp. 183-199, 2006.

[51] M. Erdmann and B. Horsfield, "Enhanced late gas generation potential of petroleum source rocks via recombination reactions: evidence from the Norwegian North Sea," Geochimica et Cosmochimica Acta, vol. 70, no. 15, pp. 3943-3956, 2006.

[52] F. Behar, M. Vandenbroucke, S. C. Teermann, P. G. Hatcher, C. Leblond, and O. Lerat, "Experimental simulation of gas generation from coals and a marine kerogen," Chemical Geology, vol. 126, no. 3-4, pp. 247-260, 1995.

[53] J. R. Levine and W. E. Edmunds, Structural geology, tectonics, and coalification, Carboniferous Geology of the Anthracite Fields of Eastern Pennsylvania and New England, Geological Society of America, Coal Division, 1993.

[54] M. Teichmuller and R. Teichmuller, "The significance of coalification studies to geology: a review," Bulletin des Centres de Recherches Exploration-Production Elf-Aquitaine, vol. 5, no. 2, pp. 491-534, 1981.

[55] Z.X. He, A. Q. Fei, and T. H. Wang, The Ordos Basin Evolution and Hydrocarbon, Petroleum Industry Press, Beijing, 2003.

[56] Z. X. He, J. H. Fu, S. L. Xi, S. T. Fu, and H. P. Bao, "Geological features of Sulige gas field," Acta Petrologica Sinica, vol. 24, no. 2, pp. 6-12, 2003.

[57] D. Liu, C. Yu, S. Huang, C. Fang, Z. Feng, and Q. Kong, "Using light hydrocarbons to identify the depositional environment of source rocks in the Ordos Basin, central China," Energy Exploration \& Exploitation, vol. 33, no. 6, pp. 869-890, 2015.

[58] J. S. Seewald, M. Y. Zolotov, and T. McCollom, "Experimental investigation of single carbon compounds under hydrothermal 
conditions," Geochimica et Cosmochimica Acta, vol. 70, no. 2, pp. 446-460, 2006.

[59] X. Xia and Y. Gao, "Mechanism of linear covariations between isotopic compositions of natural gaseous hydrocarbons," Organic Geochemistry, vol. 113, pp. 115-123, 2017.

[60] Y. Tang, Y. Huang, G. S. Ellis et al., "A kinetic model for thermally induced hydrogen and carbon isotope fractionation of individual $n$-alkanes in crude oil," Geochimica et Cosmochimica Acta, vol. 69, no. 18, pp. 4505-4520, 2005.

[61] Y. Ni, J. Gao, J. Chen, F. Liao, J. Liu, and D. Zhang, "Gas generation and its isotope composition during coal pyrolysis: potential mechanism of isotope rollover," Fuel, vol. 231, pp. 387-395, 2018. 

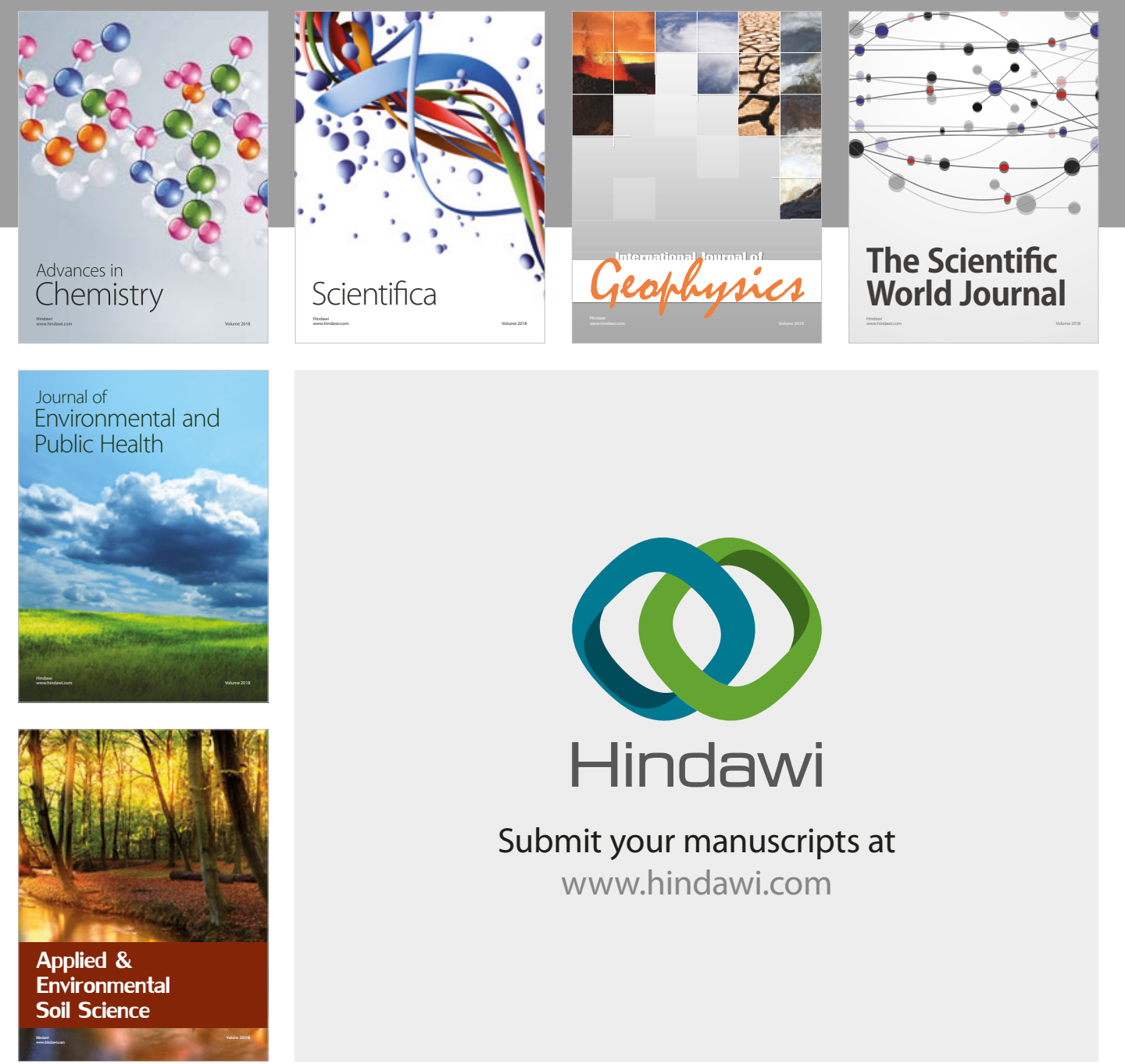

The Scientific

\section{World Journal}
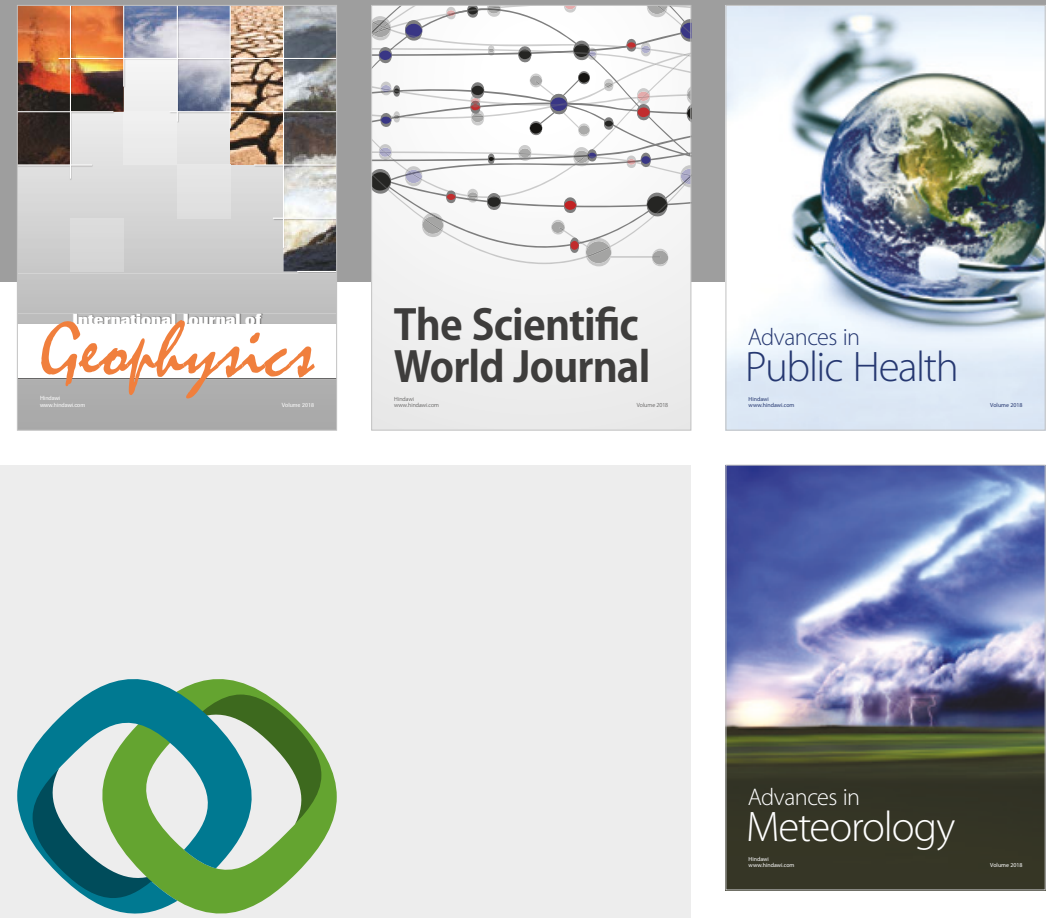

Advan

Public Health

\section{Hindawi}

Submit your manuscripts at

www.hindawi.com
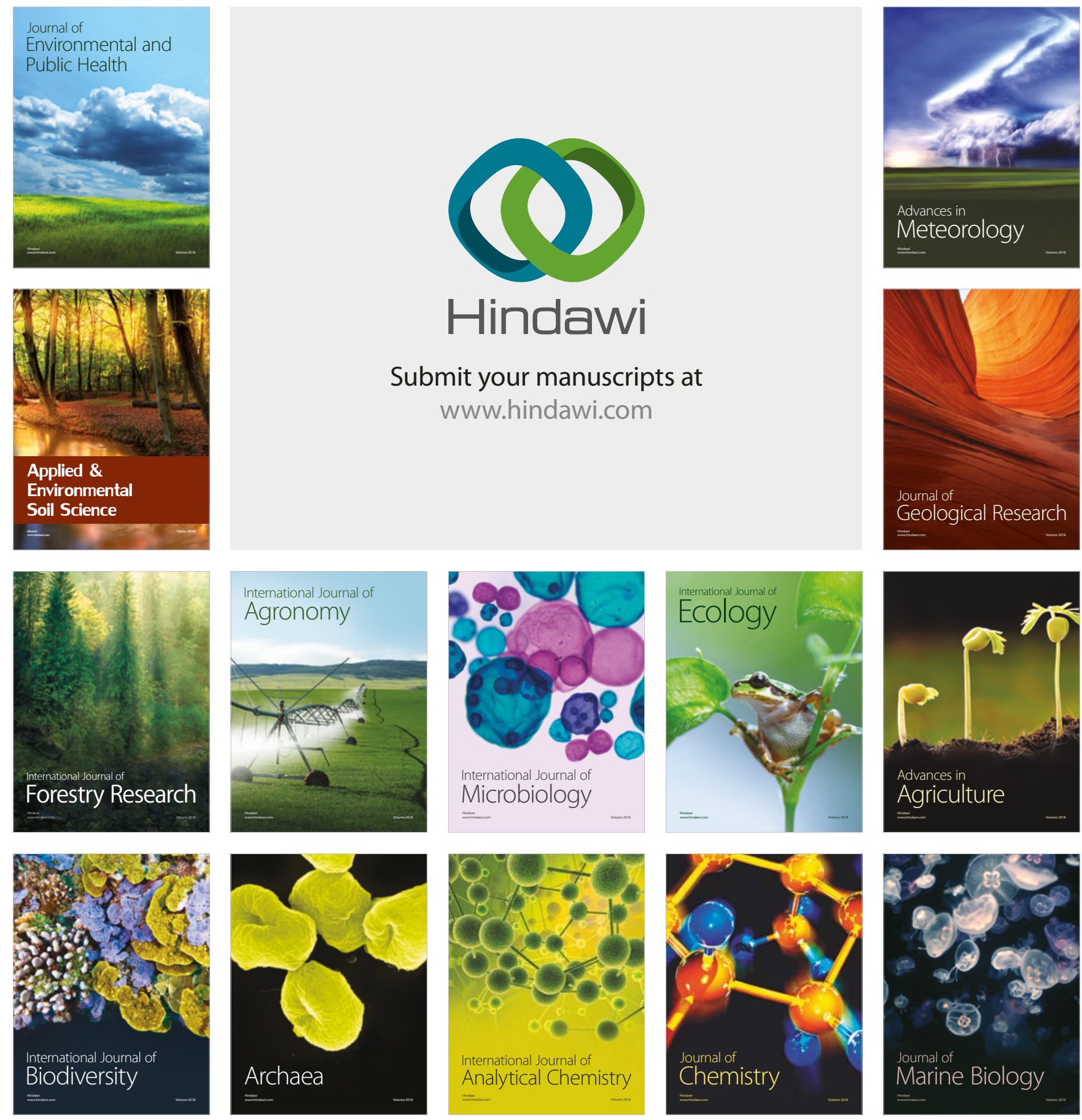